Rhode Island College

Digital Commons @ RIC

Master's Theses, Dissertations, Graduate

Master's Theses, Dissertations, Graduate Research and Major Papers Overview Research and Major Papers

$5-1-2013$

\title{
A Palliative Care Program Evaluation
}

Kathleen M. Robinson

Rhode Island College

Follow this and additional works at: https://digitalcommons.ric.edu/etd

Part of the Nursing Commons

\section{Recommended Citation}

Robinson, Kathleen M., "A Palliative Care Program Evaluation" (2013). Master's Theses, Dissertations, Graduate Research and Major Papers Overview. 223.

https://digitalcommons.ric.edu/etd/223

This Major Paper is brought to you for free and open access by the Master's Theses, Dissertations, Graduate Research and Major Papers at Digital Commons @ RIC. It has been accepted for inclusion in Master's Theses, Dissertations, Graduate Research and Major Papers Overview by an authorized administrator of Digital Commons @ RIC. For more information, please contact digitalcommons@ric.edu. 


\section{A PALLIATIVE CARE PROGRAM EVALUATION}

by

Kathleen M. Robinson

A Major Paper Submitted in Partial Fulfillment of the Requirements for the Degree of

Master of Science in Nursing

in

The School of Nursing

Rhode Island College

2013 


\begin{abstract}
Palliative care is a growing field in response to the healthcare needs of people suffering with the consequences of serious health issues. As an evolving specialty, palliative care needed criteria to denote and measure quality. National leading specialist in palliative care have developed and promoted standards for care and excellence in this field, however, it is critical for palliative care programs to evaluate the manner and extent to which these standards are incorporated into their care. A program evaluation of an existing Palliative Care Program at a VA hospital was undertaken. National guidelines and standards, that specify preferred structures and practices for quality palliative care, were compared to the VA Hospital's Palliative Care Program implementation and operationalization. The program demonstrated and met most of the attributes and characteristics identified as essential markers of a quality palliative care program. Strengths of the program and opportunities for growth and development were discussed as well as implications for future programs including the role of the advanced practice nurse in this important specialty.
\end{abstract}

Keywords: palliative care, program evaluation, VA hospital 
Acknowledgements

Kathleen Gremel PhD, R.N.

Peggy Matteson PhD, R.N.

Donna Horrocks MS, RN, CNS-BC

Laura Mercer, MSN, ANP-BC

Susan Cessario LICSW

Jim Howard PhD

Kenneth Robinson 


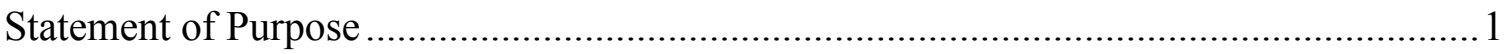

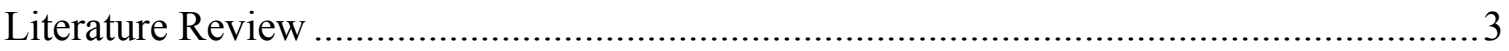

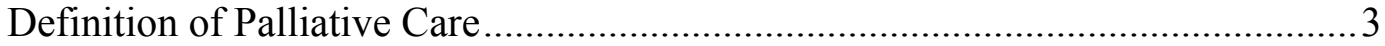

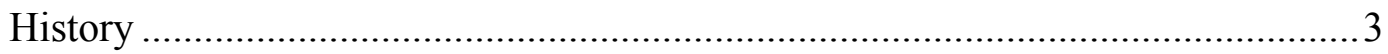

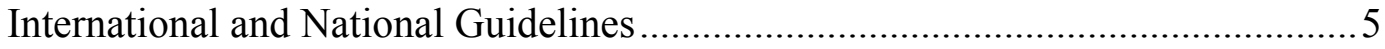

National Guidelines for Palliative Care .........................................................6

Palliative Care Measurements in the Literature ............................................... 7

Structural and Procedural Measures ................................................................. 9

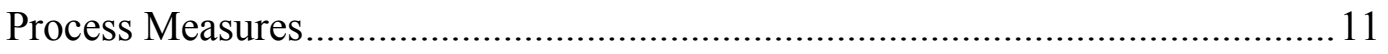

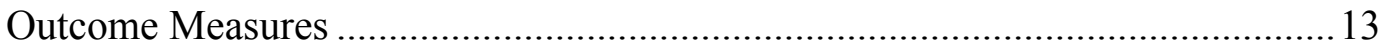

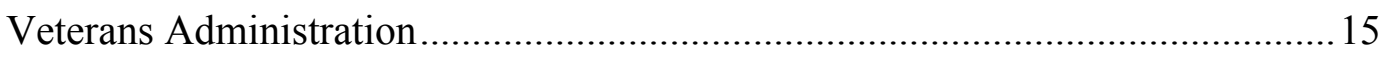

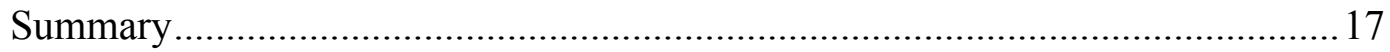

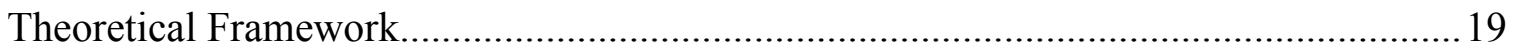

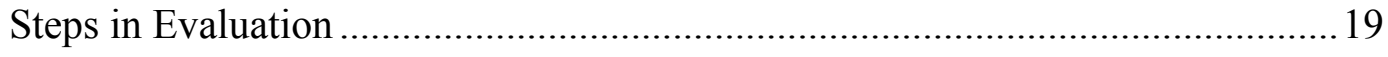

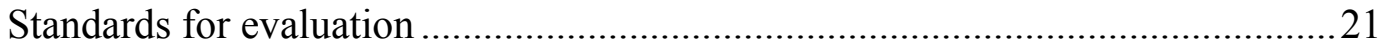

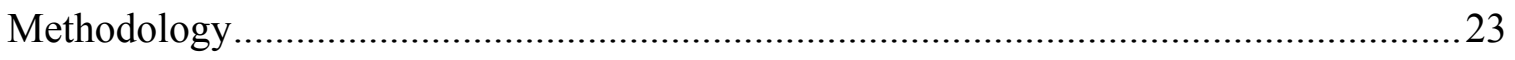

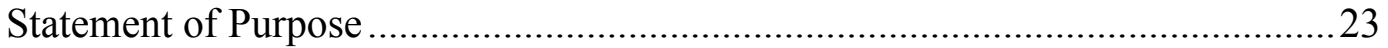

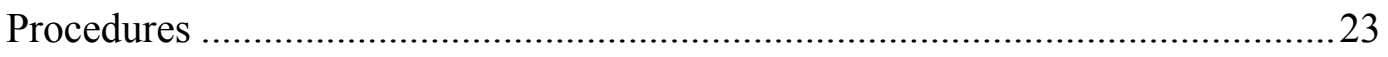

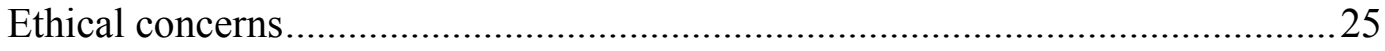




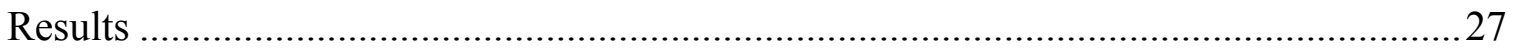

Structure of the Palliative Care Consult Team .....................................................2

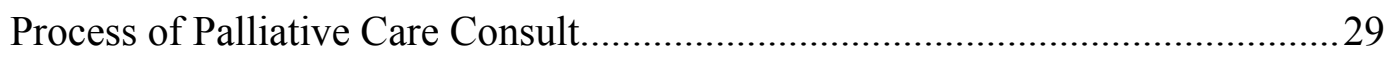

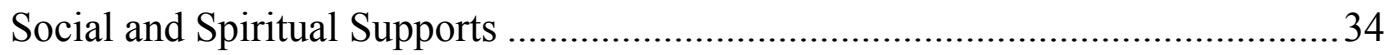

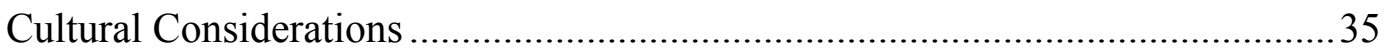

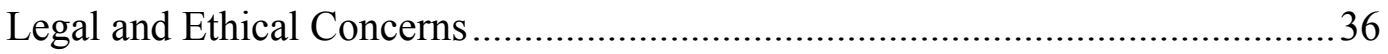

Death, Grief and Bereavement Care................................................................ 37

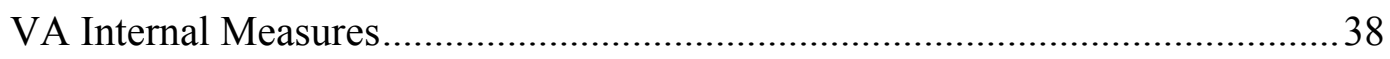

Team Members Perceived Strengths and Barriers to Care .....................................38

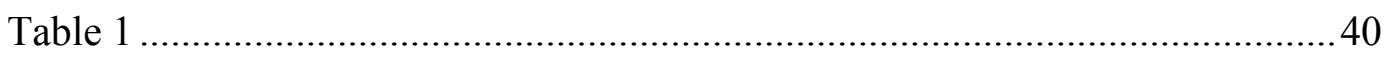

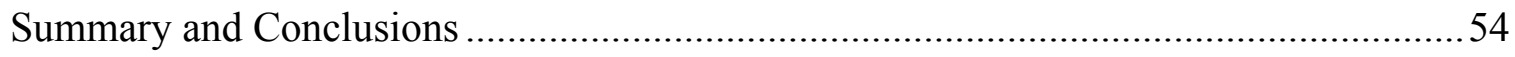

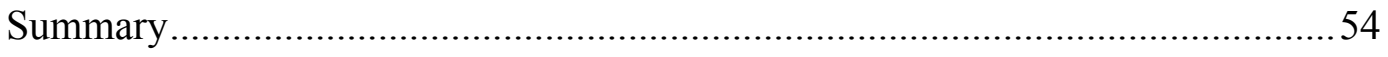

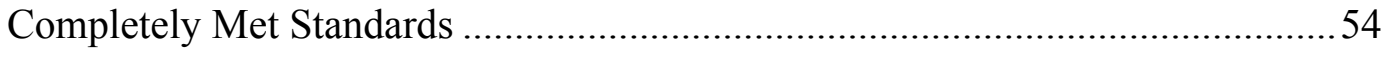

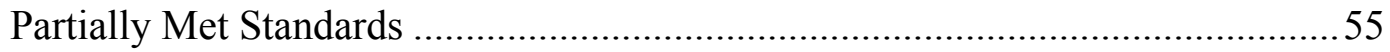

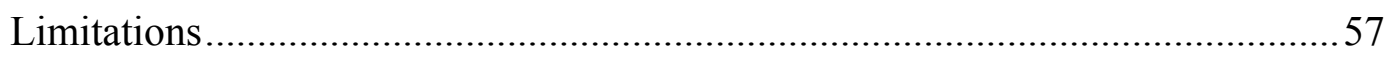

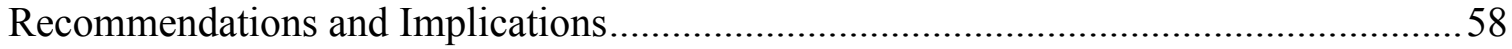

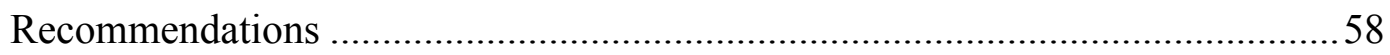

Standards and Framework ………….............................................................59

Advanced Practice Registered Nurses ............................................................6

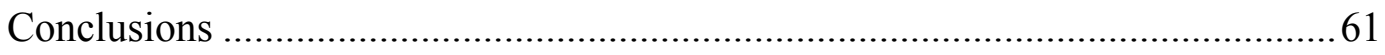

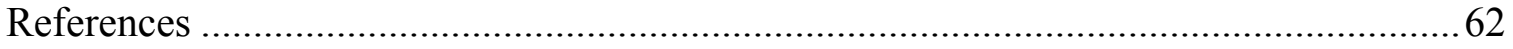

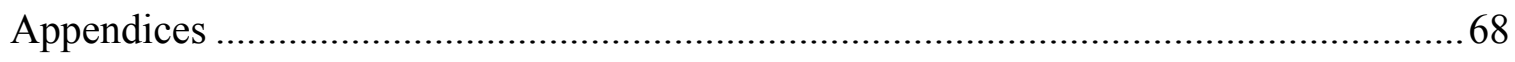




\section{Background/Problem Statement}

Advances in medical technology and pharmacology have dramatically increased life expectancy. Diseases such as cancer, once considered terminal, are increasingly more likely to be considered a chronic, serious and complex illness. The altered trajectory of many disease progressions has greatly impacted the medical needs and services of the seriously ill. The American healthcare system is experiencing unprecedented medical, financial, and administrative demands in part due to the growth of its aging population and those that must contend with multiple co-morbid conditions. In addition to the increased stressors placed upon the American healthcare system, it is simultaneously undergoing a fundamental and historic change in the manner in which care is delivered and reimbursed. It is imperative that healthcare programs meet the needs of the population in an effective and cost efficient manner (Morrison, Maroney-Galin, Kralovec \&Meier, 2005).

One such program is palliative care. Palliative care programs are designed to address the needs of patients with chronic, serious illness by delivering comprehensive care aimed at addressing symptom management hence alleviating suffering of patients

and their families. According to the Center to Advance Palliative Care (CAPC), palliative care programs in United States hospitals have continued to increase for the tenth consecutive year (CAPC, 2011). The growth of hospital based palliative care programs has risen from 658 to 1568 during the years of 2000-2009, reflecting an increase of $138.3 \%$ (CPAC, 2011). Although there has been a great increase in the number, scope and sophistication of hospital palliative care programs there still remains great variability 
in the operationalization of programs. This variation makes it difficult to compare programs and presents a challenge when evaluating quality, cost, and patient satisfaction.

While there exist many different approaches and implementation of hospital palliative care programs throughout the United States, there is a model of palliative care that has been implemented nationally within the Veterans Administration (VA) Hospital System. The VA has not only embraced the concept of hospice but has become a leader in the evolving specialty of palliative care (Shreva, 2010). The VA has mandated that all if its facilities have Palliative Care Consultative Teams (PCCT) in place by 2003. The recommendations that the specialties of nursing, medicine, social work and chaplain services were crucial components of the PCCT. Once the mandate of an existing PCCT was met in each VA facility, many initiatives to promote and enhance the provision of excellence in palliative care practice were undertaken (VHA directive, 2008).

In the interest of continuing quality improvement of the PCCT, a program evaluation of a VA Palliative Care program was performed at an unnamed VA acute care hospital. A multi-dimensional approach including review of internal documents, charts, observation and personal interviews was utilized in the process of evaluation. The CDC framework for program evaluation was utilized as the theory for the evaluation design. 


\section{Key Literature Review}

\section{Definition of Palliative Care}

The terminology of "palliative care" has been utilized and seen in the literature for over 30 years, however, a universal definition and concept analysis has remained ambiguous as the evolving specialty is still in the early forms of development (Pastrana, Junger, Ostegathe, Elsner, \& Radbruch, 2008). Definitions are important as they can serve as an impetus for program development, evolution and changes in practice. A working definition of palliative care is essential to identify the key elements, structures and practice of care. Having a definition of palliative care that includes what it is and the kind of interventions it provides is critical-prior to the undertaking of any efforts of evaluation. The World Health Organization (WHO) defines palliative care as " an approach that improves the quality of life of patients and their families facing the problems associated with life-threatening illness, through the prevention and relief of suffering by means of early identification and impeccable assessment and treatment of pain and other problems, physical, psychosocial and spiritual” (WHO, 2012).

\section{History}

The early forms of palliative care in the United States emerged as an adaptation of the hospice movement developed in the United Kingdom (Connor, 2007). Dr. Cicely Saunders (United Kingdom, 1967) is credited as the founder of hospice care (National Hospice and Palliative Care Organization, 2012). Hospice care emerged through a philosophy of meeting dying patient's needs. Fundamental to the hospice values was a team approach and focus on the care of the whole person. 
In 1974, the first United States hospice opened in Branford, Connecticut (National Hospice and Palliative Care Organization, 2012). The implementation and development of hospice in the U.S. was greatly influenced by the culture and pervasive attitudes around death as a "failure" of medicine. Understanding the concepts and attitudes, associated with hospice care, are critical in the context of implementation, development and evaluation of palliative care programs since they share many common themes. (Connor, 2007)

Although palliative care has its beginnings through the hospice movement, it is important to distinguish that they are not the same. Hospice and palliative care share similar goals of symptom relief and pain management; they differ primarily in that palliative care may be provided at any age and at any stage of the disease process (National Institute of Health, 2005). Palliative care may be provided in conjunction with aggressive and curative treatment modalities.

Within the United States, hospice care is reserved for the last six months of life and it specializes in end-of-life care. As alternatively it is recommended that palliative care be implemented early in the management of a serious illness (Hauser et al., 2011). In the United States palliative care programs have faced many difficulties in implementation due in part to the fragmented healthcare system, challenges related to regulations governing reimbursement, and an overall status of inadequate or lack of training of medical providers (Connor, 2007; Hauser et al., 2011). 


\section{International and National Guidelines}

National and international palliative care experts have formed coalitions to collaborate and promote palliative care. These coalitions have begun to clarify the concept of palliative care, identify quality indicators and make recommendations for further research. While consideration must be given to international palliative care expert opinions and recommendations, the uniqueness and complexities seen within the United States healthcare system suggest that national guidelines take precedence for this program evaluation. Measuring palliative care outcomes has been challenging due to complexities unique to the palliative care population, the intricacies within care domains and many cultural and societal variances (Eagar, Walters, Crow, Aoun, \& Yates, 2010; Jocham, Dassen, Widderhoven, \& Halfens, 2009).

In 2004, leading palliative care organizations in the United States, gathered together to identify, clarify and delineate essential elements, precepts and structures of quality palliative care. The result of their work was the formation of the National Consensus Statement and Guidelines for Quality Palliative Care (National Consensus Project for Quality Palliative Care (NCP), 2004). These guidelines are applicable to palliative care programs in a variety of settings. They are inclusive of all ages across the lifespan with the specific goal of alleviating suffering for those facing serious health challenges at any point along the continuum of medical care. The goal of the clinical practice guidelines are to improve the quality of palliative care in the United States by decreasing the variations in programs, fostering a continuity of care across settings and to 
encourage collaboration among palliative care organizations with hospices and other health care facilities (NCP, 2009).

\section{National Guidelines for Quality Palliative Care}

It is imperative that healthcare programs deliver care that meets the needs of all populations in an ethically effective and economically sound manner. Quality improvements and clinical measurement of health care have been identified as a national priority by the Institute of Medicine (Institute of Medicine (IOM), 2001). This priority applies to palliative care.

The guidelines set forth by the national consensus statement were groundbreaking in the area for U.S. palliative care organizations. In the document, The Clinical Guidelines for Quality Palliative Care, eight domains of care were identified; each with specific professional behaviors and methods of service delivery to support quality care. The domains of palliative care identify care of the patient and family in a manner consistent with care of the whole person. As noted by the NCP (2009), the eight domains are as follows:

Domains of Quality Palliative Care

1. Structure and Processes of Care

2. Physical Aspects of Care

3. Psychological and Psychiatric Aspects of Care

4. Social Aspects of Care

5. Spiritual, Religious and Existential Aspects of Care

6. Cultural Aspects of Care 
7. Care of the Imminently Dying Patient

8. Ethical and Legal Aspects of Care (p.616).

Currently, societies such as Sigma Theta Tau International, End of Life Nursing Consortium, Hospice and Palliative Nurses Association, American Geriatric Society and The American College of Nurse Practitioners are among the many professional organizations to endorse this National Consensus Clinical Project Guidelines (NCP, 2009). These guidelines identify the domains of palliative care as well as delineate professional behaviors and delivery to adhere to clinical practice guidelines.

The National Quality Forum (NQF), a nonprofit organization that seeks to improve American healthcare, identified palliative care and hospice care as national priorities for health improvement (NCP, 2009). The NQF endorsed the clinical practice guidelines as set forth by the NCP. The quality group not only identified 38 preferred practice behaviors that embodied the guidelines as established by the NCP; they were in keeping with the IOM's six dimensions of quality healthcare (NQF Consensus Report, 2006). In 2009, the most recent and updated National Consensus Clinical Practice Guidelines were published to be both current and in concordance with the NQF's preferred practices (NCP, 2009). The NQF's recommendations serve as a framework for new palliative program development as well as standards of objective measurement and performance behaviors to evaluate existing programs.

\section{Palliative Care Measurements in the Literature}

The aim of the literature review was to identify methodologies and measurements most effective in evaluating palliative care. Additionally, the review sought to examine 
questions of evaluation as it relates to palliative care, identify gaps in the literature and suggest areas for future exploration in an effort to measure and promote effective, quality palliative care. A systematic review of the literature was conducted utilizing Pub-Med, CINAHL, and OVID databases. The broad terminology and concept analysis of palliative care was initially explored as the focus of the review, followed by a more specific analysis of quality indicators, as well as measurements and criteria associated with quality palliative care. To structure this search, the following terms were used: palliative care, quality of palliative care, standards of palliative care and guidelines of palliative care. Research articles, consensus statements, policy statements and guidelines were included from the time of 2001-2012. References earlier than 2001 were used to validate standardized scales and to discuss the evolution of the conceptualization and operationalization of palliative care. Only articles published in English were considered for inclusion.

The literature review revealed several approaches and measures that may be utilized when evaluating a program. Often benchmarks and quality indicators are considered in the evaluation process (Agency for Healthcare Research and Quality [AHRQ], 2012; Bakitas, Bishop, Caron, \& Stephens, 2010; Weissman \& Meier, 2008). While both of these strategies may be helpful they are not exhaustive or conclusive measures of quality. Another, perhaps more complex approach to program evaluation was to review in depth aspects of structure, process and outcomes for measurements of quality. 


\section{Structural and Procedural Measures}

The National Consensus Project Clinical Guidelines, (2009), have given specific structural and process measures that would promote quality palliative care programs. The NCP has set forth these guidelines with an acknowledgment that they represent an ideal and it may not be possible for all programs to implement all the elements. The preferred behaviors are a gold standard, a model to aim towards. The recommendations have been broken down into two subcategories; "Must Have", characteristics that are minimally essential, and the latter "Should Have", the ideal structure and processes. For example, the "Must Have" measure regarding availability of inpatient services is that palliative services must be available Monday to Friday for inpatient consultation with 24/7 telephone support. A "Should Have "practice is that there should be $24 / 7$ availability for inpatient palliative care services for hospitals with greater than 300 beds (Weismann \& Meier, 2008).

Several themes relating to structural measures emerged throughout the literature; one theme was palliative care must be delivered throughout a variety of settings and throughout the lifespan (Hauser et al., 2011; NCP, 2009; NQF Consensus Report, 2006; The Joint Commission, 2011). Other themes were recommendations for the provision of palliative care services by specialty trained interdisciplinary team members. Another common concept throughout the literature was the focus of care to be relief of pain and other distressing symptoms including physical, psychosocial and spiritual (Bakitas et al., 2010; NQF Consensus Report, 2006). The importance of continuity of care including methods that support care for the immediately dying, support for the families and 
bereavement services was a common structural requisite throughout the literature (NCP, 2009; National Hospice and Palliative Care Organization, 2012; Weissman \& Meier, 2008) .

In 2008, the Centers for Medicare and Medicaid Service (CMS) contracted with the Quality Improvement Organization in North and South Carolina to develop quality measures to assess hospice and palliative care (Schenck, Rokoske, Durham, Cagle \& Hanson 2010). The group identified a list of quality measures that reflected the NCP domains of palliative care. The published work is known as the PEACE project. The technical expert panel recommended quality measures that primarily focused upon alleviation of symptoms with an emphasis on symptoms of pain, dsypnea, nausea, anxiety and depression. While acknowledging the many domains of palliative care, there was a clear lack of attention to measurements in the areas of spiritual, cultural, and social domains (Hanson, Scheunemann, Zimmerman, Roakoske, \& Schenck, 2010; Schenck, Roakoske, Durham, Cagle \& Hanson 2010). Although the study did demonstrate there are numerous instruments available to measure the many domains of palliative care; they could not conclusively recommend one tool as superior due to variances in patient populations, settings and needs.

In recent years, palliative care has become integral to care in many intensive care units. A consensus work group was formulated to acknowledge and establish characteristics of "quality palliative care' in this distinct setting. The resulting consensus statement from the Robert Wood Johnson Foundation Critical Care Workgroup identified several structural and procedural measures that would serve as preliminary indicators of 
quality palliative care (Mularski et al., 2006). While the identified measures are consistent with the NCP and NQF's domains, there are some differences, based upon the uniqueness of caring for the hospitalized critically ill patient. Differences are the timely identification of decision makers, early identification of goals of care, symptom management and support for patient and families. Strong, clear communication skills of providers, as well as continuity of care were also identified as indicators of quality care.

\section{Process Measures}

When evaluating the procedural methods of a program, it is often useful to monitor clinical metrics, such as the charting of a daily pain assessment. The process of palliative care is the actual caring activities that occur, the interactions between the patient/family and the providers (Weismann, Morrison, \& Meier, 2010). CPAC in conjunction with national interdisciplinary palliative care experts agreed in a consensus statement, that the most important areas for clinical metrics include pain and symptom management, patient centered goals of treatment, documentation of support to patient and caregivers, and transitional management documentation (Weismann, Meier and Spragene, 2010). The methodology to assess these clinical metrics was described as patient chart audit and reviews for documentation of these domains of care and critical processes.

From a global perspective, the International Association for Hospice and Palliative Care (IAHPC) gathered to identify goals for essential practices in palliative care. Their work focused on identifying palliative care that could be performed by healthcare providers the primary care level that could be applicable in all socioeconomic 
settings. The "essential" components identified were similar and consistent with processes recommended by palliative care experts in the United States. The IAHPC then prioritized their list of essential practices. Preference was given to critical practices that focus on the identification, treatment and care for the physical and psychological domains; specifically; pain management, dsypnea, anxiety, depression and delirium. The IAHPC further recommended that attention be given to other domains of care including spiritual, grief and bereavement needs whenever possible. The importance of effective communication and coordination of treatment was recognized as a highly valued skill and essential component for quality palliative care (De Lima et al., 2012).

Throughout the literature there was the common theme of the importance of the physical domain and symptom management. The focus on physical domain and symptom management affirms the mission and overall objectives of palliative care; a reduction in suffering experienced by patients with serious illness. Various tools were utilized in different settings to evaluate pain, dsypnea, anxiety, depression, and quality of life. Again, no singular tool could be universally identified for usage based upon differences in patient's settings, disease processes, culture and needs (Hanson, Scheuenemann, Zimmerman, Roakoske, \& Schenck, 2010; Twaddle et al., 2007). Clinical metrics and benchmarks are not conclusive measures of quality; however, they do assist in the necessary data collection to further development of quality indicators and thus is a recommended practice (AHQR, 2011; Nolte, 2010). 


\section{Outcome Measurement}

Another category of literature is related to outcomes. Outcome measurement and research seeks to correlate interventions in healthcare with desired results. Dy, Lupu \& Scow, (2012) stated that in spite of many utilization measures, quality measures remain a challenge in the field of palliative care. The argument is made that measurement of quality palliative care remains an elusive goal due to the challenges presented by this vulnerable population and lack of consistent documentation of many key aspects of endof-life care (Dy, Lupu, \& Scow, 2012).

Several areas of outcome measurement seen in the literature relate to symptom management, quality of life measurements (QOL), and patient/ family satisfaction. Jocham, Dassesn,Widderhoven \& Halfens (2009) noted that the prevalence of symptoms and symptom management is often described in the literature, but there is little consistency between various studies, both in the populations considered and the tools utilized to measure outcomes (Jocham, Dassesn, Widderhoven \& Halfens (2009).

A goal of palliative care is often described as seeking to improve patient and families QOL. Many studies focus on measurements of QOL, yet despite the stated importance of QOL, there remains no standard conceptual definition or universal measurement of QOL (Hanson, Scheuenemann, Zimmerman, Roakoske, \& Schenck, 2010; Hauser et al., Jocham, Dassen, Widderhoven \& Halfens, 2009). Difficulty in assessing satisfaction in the palliative care population is cited repeatedly as a barrier to outcome measurement due to the inherent complex nature of the terminally ill, 
specifically, cognition near end of life (Jocham, Dassen, Widderhoven \& Halfens, 2009; Selman \& Harding, 2010).

Two palliative outcome measurement tools frequently cited in the literature are the Palliative Outcome Scale (POS) (Hearn \& Higgins, 1999) and the Support Team Assessment Schedule (STAS) (Bausewein, LeGrice, Simon\& Higginson, 2011). The POS is intended for patient use while the STAS is utilized by staff members. Both of these tools measure many of the domains important in palliative care. They specifically address many of the physiological, psychological, spiritual, communication and support systems critical for palliative care. However, results are reported as summary scores and therefore may not reflect the multi-dimensional nature of some of the problems facing the individuals. Neither of these tools have the ability to reflect cultural variations or problems that may occur in the ethical and legal domains of palliative care. (Bausewein, LeGrice, Simon, \& Higginson, 2011). These tools were developed in the United Kingdom and have now been translated and validated for use in a variety of languages and cultures.. The tools are designed to be concise, completed in less than 10 minutes and reflect the patient's status across a wide range of domains of palliative care. Some have argued that there is not possible to capture the depth of a symptom such as pain in one question. Both the POS and the STAS may assist in palliative care outcome measurement yet the existence of so many variations of the original tools may have actually weakened its validity. Some adaptations of the tool have not been tested for reliability and validity. An additional limitation is that all practitioners do not always clearly specify which 
version or adaptation of the tool they have used. (Bausewein et al., 2011).

The Australian task force for palliative care has also established an assessment tool to enhance clinical practice. The Palliative Care Outcomes Collaboration, (PCOC), has recommended frequent assessments of level of care, symptoms, functionality and severity to facilitate quality improvement and assist in measurement of outcomes. While this tool and clinical practice has become standardized in Australia, it is in its initial phase of development and requires further research to validate its usefulness to measure outcomes (Eager, Elaters, Crow, Aoun \& Yates 2010).

\section{Veterans Administration}

The review of the literature specific to the veteran population reveals the United States Department of Veterans Affairs (VA) has provided extensive palliative care services within the VA system. In May 2003, the VA mandated that all VA facilities were to have a Palliative Care Consultative Team. The mandate also made recommendations for the composition of that team to include nursing, medicine, social work and chaplain services as well as requirements for annual reporting (Shreva, 2010). A long standing goal of the palliative care program has been to reduce the variability in end-of-life care throughout the national VA system. Consistent with national standards, the VA system has implemented palliative care programs in each of its inpatient hospitals as well as a growing number of home-based primary care teams. Specially trained palliative care experts from a variety of disciplines provide the care. The care is patient focused and is delivered in a timely and efficient manner (Shreva, 2010). 
Despite the consistency with and availability of recommended practices by the NCP and NQF, the VA's hospice and palliative care (HPC) program developed its own quality improvement measures and processes. The VA has developed three national centers: the Performance Reporting and Outcomes Measurement to Improve the Standard of Care at End-of-life (PROMISE) Center, the Quality Improvement Resource Center (QuIRC), and the Implementation Center. The PROMISE Center has promoted quality by identifying quality indicators and by gathering quality data by administering the Bereave Family Survey (BFS). The QuIRC Center has improved quality by providing tools and resources to standardize the process of palliative care. Lastly, the Implementation Center has provided leadership training for facility palliative care programs. This center also fostered quality improvement by piloting quality improvement initiatives based upon the feedback from the BFS. They have provided a valuable service of disseminating processes of care that the VA has determined to be best practices for end-of-life care for veterans.

The HPC at the VA has partnered with leading palliative care organizations such as CPAC and the Hospice and Palliative Care Nursing Association to develop veteran specific curricula and to increase their own expertise in the specialty of palliative care. The VA has adopted the definition of effective palliative care programs as those that “include regional leadership, dissemination of expertise, and effective information system, continuous quality improvement, the engagement of stakeholders and the fostering of research" (Shreva, 2010, p. 49). Having established an internal process and three centers to collect, evaluate, and disseminate quality data, the VA is setting forth 
new goals. Leadership has embraced an initiative to make the access of palliative care available to all veterans in need, especially those veterans outside VA hospitals.

\section{Summary}

The focus throughout the literature review has been to identify useful methodologies and measures to determine quality palliative care. First considered were the structural and procedural methods and measures. Experts, patients and families receiving care defined the structural processes that are associated with quality palliative care programs. These processes include specialized care by a team, whose focus was minimizing or alleviating the distressing symptoms related to serious illness. Effective pain management was also consistently identified as an indicator of quality, in addition to management of symptoms like dsypnea, anxiety and depression. Structures and processes that promote patient/family-centered goals have been determined to also be quality characteristics. Effective communication was consistently identified as a critical component of quality palliative care programs. Furthermore families identified the importance of support for grief and bereavement services. Well-coordinated continuity of care, especially when transitioning at different stages of the disease process, was determined to be vital elements in a quality palliative care program.

Second, outcome measurements were also determined to be important measures of palliative care programs; however, studies in the literature suggest that tools utilized for outcome measures are inconsistent. They lack unanimously accepted definitions, consensus regarding terminology and poorly defined limits in outcome research. Universal outcome measurement poses a challenging and inconsistent method to evaluate 
palliative care due to the inadequacy of research at this time. In addition to the gaps in the literature regarding outcome measurement, a lack of mechanisms to assess the social, cultural and spiritual domains of palliative care was noted.

The program evaluation will discuss the method of social, cultural and spiritual support present in the VA Palliative Care System. Further research in these domains as well as methods of measurement would potentially rend valuable information important for future evaluation. 


\section{Framework Used for Evaluation}

As in other areas of healthcare, programs must have systematic manner in which to be measured and evaluated. The Centers for Disease Control and Prevention (CDC), has developed, utilized and recommended an effective approach for public health program evaluation (Milstein \& Wetterhall, 2000). The framework has two parts; steps in evaluation practice and standards for effective evaluation.

\section{Steps in Evaluation}

According to the CDC framework, there are six steps in the evaluation practice that must be considered in any program evaluation. Because the steps are designed to be interdependent, they are often considered in a cyclical or non-linear conceptualization. They will however, be presented as linear steps with the understanding that it is a continuous process.

Step one is identified as engaging the stakeholders. Since most programs involve several key participants, it is important to identify and engage all those affected. In the instance of evaluation of a palliative care program; the stakeholders would be the patients and families receiving the care but also all that provide care and those who may benefit or be affected by the program. Palliative care physicians, nurses, social workers, volunteers, spiritual leaders as well as the hospital, community and insurance companies are all potential stakeholders in this scenario. Additional potential stakeholders such as professional organizations, partnerships with hospice facilities, advocacy groups or competitors may need to be considered (Millstein\& Wetterhall, 2000). 
Step two is to describe the program and its context. In program evaluation it is essential to convey a general statement regarding the identified need for the program, the type of services to be provided, the targeted population and the desired effects. The description of the program should reflect the mission statement and objectives of the program. It is important to explore available resources that support the program. Other considerations in the description of the program are the setting of the activities and the effects that may have on program development. Programs are dynamic; it is vital to explore the current stage of development of the program include for short-term and longterm growth and development. The principle standard of utility is demonstrated through this step of program evaluation. The program and the evaluation process should be performed from the point of the needs of the intended users (Millstein\& Wetterhall, 2000).

Step three focuses the evaluation design. A focused design, one that evaluates the areas of greatest concern for the stakeholders should be done efficiently and timely. Program evaluations are conducted for different reasons; it is essential that the purpose for the evaluation be clearly articulated. Understanding the purpose of the evaluation will help guide the strategy and evaluation design. The feasibility of the evaluation design is critical; it must be realistic, prudent, diplomatic and frugal (Millstein\& Wetterhall, 2000).

Step four is gathering credible evidence. Credible evidence is the raw data; the materials that will be reviewed as a means of answering the relevant questions about the program. It is the quality indicators, the measures and characteristics that will aid in evaluation. This evidence may be demonstrated in the policies and procedures that 
support the program. The use of systematic observations may be helpful in validating that national guidelines or recommendations are followed for this model of program. It may be helpful to assess any internal quality improvement or process evaluations within the program. It is critical that the information utilized is trustworthy, reliable, and credible to insure the standards of propriety and accuracy (Millstein\& Wetterhall, 2000).

The fifth step is justifying the conclusions. The data must be linked in order to formulate reasonable conclusions. It is helpful to have standards agreed upon by the stakeholders or other experts to assist in analysis or interpretation of the information gathered. The standard of propriety guides this step of evaluation. It is imperative that the evaluation be conducted legally, ethically and with regard for the welfare of those involved and affected (Millstein\& Wetterhall, 2000).

Lastly, the sixth step is to ensure use and share lessons learned. Valuable information must be shared with the stakeholders in order to facilitate the conclusions or recommendations. Regardless of the primary purpose of the evaluation, a thorough and effective process should yield useful information for future program development. It is important that the evaluation processes and findings are used and disseminated appropriately (Millstein\& Wetterhall, 2000).

\section{Standards for Evaluation}

The second part of the program framework is the standards for evaluation. These standards serve to provide sound guidelines for conducting reasonable and fair evaluations; they are guiding principles. The four categories for standards are utility, feasibility, propriety, and accuracy. The utility standard considers if the needs of the users 
are satisfied. This addresses who will be impacted by the evaluation, the amount and type of information that will be collected; the values used interpreting evaluation findings and the clarity and timeliness of the reports. The feasibility standard requires that the evaluation is possible and practical. Resources utilized to conduct the evaluation must be prudent and produce valuable findings. The propriety standard ensures that ethical guidelines are used so that the evaluation process used protects the welfare of human subjects, discloses the findings in and unbiased and ethical manner, and any conflicts of interest be addressed and disclosed. The last standard described by the CDC is that of accuracy, that the evaluation findings correctly represent the program. A clear purpose, method of evaluation and systematic design should ensure that there is accuracy in the evaluation findings (CDC, 1999; Millstein\& Wetterhall, 2000). 


\section{Methodology}

An evaluation of a palliative care program was completed at an acute care Veterans Administration Hospital. The evaluation process was completed utilizing a multi-dimensional approach including data collection via observation, personal interviews, chart audit and review of current VA policies, procedures, directives and mandates.

\section{Purpose}

The purpose of this program evaluation was to determine whether the VA Palliative Care Program implemented at an inpatient acute care VA hospital with less than 100 beds, located in the northeastern part of the U.S. is reflective of the NQF's recommendations for preferred practices for Palliative and Hospice Care Quality. A secondary goal of the evaluation was to determine if the VA's Hospital Palliative Program was consistent with the standards as set for the by the VA's National Palliative Care Program initiatives and mandates.

\section{Procedures}

In October 2012, endorsement of the proposed program evaluation was considered and received from the Palliative Care Program Director at the VA hospital. IRB exemption was granted in November 2012 from the VA hospital and Rhode Island College IRB. Data collection, interviews and observations were conducted over a 2 month span of time during January 2013 through February 2013. During the initial phase, an informal observation was conducted of the PCCT staff members as they interacted with staff, patients and families. Formal in-services were also observed as the PCCT 
educated new medical residents regarding the VA Palliative care program, including the mechanisms for referral, scope of practice, as well as the benefits to patient and family and complementary care given by medical staff. The second phase of the evaluation process was the conduction of an internal review of documents, policies and procedures that are the driving force behind the PCCT. The last phase of the process included chart audits and informal interviews with PCCT members.

The NQF's framework of 38 specified preferred and recommended practices served as guidelines for quality palliative care (Appendix A). These recommendations were considered the preferred standard: the practice implemented at the VA hospital facility was compared in both structure and process within these guidelines. The secondary goal, the internal practices of data collection, analysis and QI unique to the VA hospital system was observed for practices that were consistent with their stated policies and procedures. Lastly, methods of social, cultural and spiritual support specific to the VA population was noted as it may represent valuable insight into areas noted as deficient in the literature.

The VA Hospital Palliative Care Program and its team members were the source of data collection. Internal documents of policies, procedures, national mandates, national initiatives, mission statement, vision statements, program objectives and goals were reviewed as they may represent evidence of practice in accordance with national guidelines. Secondly, procedural information regarding referrals, intake assessment documents, treatment plans family meetings and discharge plans were observed and considered within the context of stated evaluation goals. In addition, operational, clinical, 
and customer metrics were reviewed during the survey. Examples of operational metrics included data that related to referrals, date of consults, diagnosis, patient age and gender, disposition and length of stay. Clinical metrics considered included all data related to internal symptom control scores, and psychosocial assessment score utilized by the palliative care team or other staff members. Customer metrics obtained the VA Bereaved Family satisfaction survey data was included for analysis. Retrospective chart reviews were conducted to associate consistency of policy to practice. Interviews were conducted with palliative care team members, hospital staff and associated agency staff for the purpose of assessing the structure and the process of palliative care services.

An additional purpose of the Palliative Care team member's interviews was to assess their perceived roles, responsibilities as well as their self-assessment of the quality of the palliative care program. Team member's beliefs were explored as it related to perceived strengths, weaknesses or areas for quality improvement within the VA Palliative Care Program.

\section{Ethical Concerns}

There are several ethical considerations when a program evaluation is conducted. All policy and procedural safeguards, as required by the IRB of VA Hospital and Rhode Island College IRB, were strictly followed. Safeguards included but are not limited to policies regarding confidentiality, data collection and patient rights. Additionally, all nursing professional standards, policies and practices were followed including, the American Nurses Association (ANA) code of ethics The four ethical standards as identified in the CDC framework for program evaluation, utility, feasibility, proprietary 
and accuracy also served as practicing guidelines. Lastly, it is important that the evaluation and process was not perceived as punitive, adversarial or exclusionary. The CDC framework encourages an evaluation approach that engages all stakeholders in a welcoming manner. A professional, non -judgmental and engaging approach was utilized by the researcher with all team members. 


\section{Results}

The NQF's 38 recommended practices for palliative care was the standard practice. During the evaluation process, the actual practice observed at the VA was compared to the preferred practice of care. The first several practice standards, as delineated by the NQF, focus on the composition of the palliative care team as well as their training and credentialing in the specialty field. Additionally, there are specific guidelines for the responsibilities of the team and the function that they must serve in the provision of palliative care services. The VA hospital PCCT is comprised of a multidisciplinary team including a Nurse Practitioner (NP), Licensed Clinical Social Worker (LICSW) and a Chaplain that serves as the spiritual counselor.

\section{Structure of the Palliative Care Consult Team}

The Coordinator of the PCCT is a NP. She is specially trained in palliative care and is certified by a nationally recognized group, End of Life Nursing Consortium (ELNEC). She is responsible for providing oversight for the palliative care program. Those responsibilities include collaborating and communicating with other VA teams within the region in the effort to lead to measurable improvement in palliative care. She is also responsible for the development of the palliative care program to be consistent with VHA guidelines, directives and program initiatives. The responsibilities of the program coordinator also include monitoring practices within the hospital as well as keeping in accordance with best practices in the region and within the practice of palliative care. The role includes responsibility for coordination of staff development and education, quality improvement and internal measurements of palliative care consults and resource 
management. Additionally the NP performs the role of coordinator of the program as well as being the active medical provider thus being responsible for providing care including but not limited to medical care, symptom management, family meetings and coordination of services

The second member of the PCCT at the VA is the LICSW. She performs work critical to the success of the PCCT. While working collaboratively with the NP in the many of the responsibilities of the PCCT, her primary duties relate to her specialty within her scope of practice. A strength that she brings is assessing both patient and family in their understanding of the illness and its trajectory, patient/family dynamics, resources of family, coping mechanisms, QOL, living arrangements and clarifying some initial goals of care including where the patient would like to live while receiving further care. As a member of the PCCT she is also specially trained and certified in the field of palliative care and is certified in Education on Palliative Care and End of life Care (EPEC).

The last member of the PCCT is the spiritual counselor. He is a Reverend, endorsed by the American Baptist Churches, USA and meets with all palliative care patients. He is certified in ELNEC and maintains an annual competency. He performs an initial "spiritual intake assessment". He visits patients of all religious beliefs and practices; providing spiritual care to a variety of patients at differing stages of illness and spiritual development. His assessment is included in the electronic document as well as periodic notes when he visits patients. Patients may refuse visitations by the chaplain.

The NQF recommends a more expansive complement of specialists on the PCCT such as pharmacists, mental health workers and nutritionists; the VA has access to all 
these special disciplines via consultation services. Each palliative care patient's unique needs are considered in their plan of care; these specialties are consulted to contribute to the interdisciplinary care of the patient when warranted. The composition of the VA PCCT complies with the specificities of disciplines as outlined by the NQF but is not reflective of the VA's own mandate for PCCT composition. It is lacking in the representation of a 0.25 full time equivalent of psychology or mental health provider. The VA does have access to a very strong mental health system including psychiatrists, psychologists and other mental health providers in both the acute hospital and outpatient settings.

\section{Process of Palliative Care Consult}

Twenty-four hour a day, 7 days per week coverage of palliative care services is the recommendation of service availability per the NQF. The VA hospital PCCT team works Monday through Friday 7:00 am to 4:30 p.m. and is available via phone for emergencies. One of the great strengths of this palliative care team is the staff's personal dedication and commitment to the practice of palliative care. Vacations are covered by outpatient palliative care specialist, discipline specific what does discipline specific mean. It would seem that these few critical staff members are not enough staff to meet the requirements of the facility and program. The team has devised two innovative approaches to management of patient issues off shift and during weekends. An "On Call Provider Handbook" has been created for management of issues specific to the palliative care patients. This guide serves as a quick reference for a variety of symptom management that is based on the latest evidence and research. Another creative strategy 
developed by the PCCT is the development of "Nurse Champions", specially trained unit based nurses that have additional education in palliative care and end of life symptom management. These nurse champions are advocates for the patients. They not only routinely identify patients for whom palliative care services may be appropriate, but advocate for those patients who may be experiencing poor symptom management or acute changes in condition. These nurse champions are part of a larger Palliative Care Committee within the hospital that meet monthly to assist in identifying needs of staff education, problems in the access or delivery of palliative care services and other areas for quality improvement.

Other educational responsibilities of the PCCT are to provide continuing education to all healthcare professionals. This is done via monthly in-services provided to both medicine and nursing regarding the practice, procedures for referrals, and symptom management. Nurse Champions are ELNET educated and there exists on line education modules that are available to all staff. The PCCT also works with the community, PCP's and outside the organization sharing their knowledge of palliative care and best practices.

The NQF clearly defines and specifies how palliative care should be provided to patients. It recommends that a timely, patient centered care plan be in place; one that clearly identifies goals of care and treatment. This care plan should be shared with all involved in the care of the patient and across transitions of care. Patients should be educated so that they may make informed decisions regarding their care and hospice services, which should be offered as an option to patients for whom the disease trajectory may include death within a year's time. There are several criteria that specifically address 
symptom management and side effects commonly seen in patients as they contend with complex illnesses as well as symptoms associated with the latter stages of life. The VA has policies and procedures that direct the manner in which palliative care consultations are initiated. The actual order for palliative care consult must be initiated by a licensed medical provider; however, there exist several internal mechanisms that may prompt the licensed medical provider to order the consult. A nurse driven intake symptom assessment tool is used upon admission that often prompts a possible PCCT referral. The VA medical providers have become more educated and cognizant of the benefits to the patient through palliative care. This has affected in an internal culture and paradigm shift that has resulted in many referrals made by the primary care providers as well as the providers that care for patients in the emergency department.

Once a referral to the PCCT is made, the patient is scheduled to be seen within 24 hours; however, most patients are seen the day of referral. If the patient is in need of immediate symptom management, a direct phone call from the referring provider would indicate the priority for this patient to be seen sooner. The VA PCCT's timely response to referrals not only meets the standards set forth by the NQF, they are exemplary. The PCCT conducts an intake assessment at which time the patient's general understanding of their disease process and overall health condition is assessed. The patient's goals of care are initially assessed based upon his understanding of his condition. Problematic symptoms are identified by patient and PCCT with possible plans of care and symptom management discussed. All options of care are discussed, including the option for hospice care. Each patient is treated uniquely based upon the specifics of their medical condition 
and their personal understanding and goals of treatment. After each initial PCCT consult there is a follow-up meeting with the medical team to discuss: code status, information patient may be requesting about treatment plan, goals of care, recommendation for symptom management, and or the need for a patient/family meeting. It is the medical team's responsibility to confirm the patient code status, confirm patient and family treatment plans and goals of care, and to communicate with other providers. The PCCT continues to support the patient and will facilitate a patient/family meeting with the team (medical team, specialists and PCCT) to enhance communication, formalize the care plan and to anticipate care needs upon discharge from the hospital. This meeting may also be instrumental if there exists a gap in the patient's understanding of their medical condition thus the patient is supported in making an informed decision about their care. The PCCT coordinates these meetings as part of their role in facilitating communication and planning for the patient in acute care and across transitions of care. In particularly complex medical or social situations, it may take several meetings before a comprehensive plan, one in which all vested parities consent, is finalized.

If the patient wishes to continue aggressive medical treatment, PCCT continues to support the patient/family and focuses upon symptom management, supportive services and coordination of services upon discharge. The patient becomes part of their daily caseload and is followed throughout the acute hospital stay. The patient's symptoms are measured using a validated tool known as the Condensed Memorial assessment Scale CMAS, a tool endorsed by the National Palliative Care Research Center (National Palliative Care Research Center, 2013). The CMAS is a likert scale instrument that 
measures the 14 most common multi-dimensional symptoms experienced by patients with severe, potentially life threatening illnesses. The NP is specially trained and skilled in management of the symptoms and writes orders to provide relief. Complex symptom management may require consultation with experts in pharmacy, interventional radiology or other specialists. She has access to many resources as part of a large healthcare system as well as resources made available via national palliative care organizations.

If the patient and the family choose to no longer seek aggressive medical care; the distinction between palliative care versus hospice care is explained to the patient. Often the discharge plan of care consists of palliative treatment plan with a bridge to hospice care. Families are given a VA sponsored Palliative Care brochure that explains the services provided by palliative care. The team also may offer a book entitled "Hard Choices for Loving People", a booklet discussing the difficult decisions that patients and families may be faced with in defining their goals for care. If a patient and family should opt for hospice care, the VA provides a resource, "Palliative Care Family Handbook"; this is an educational booklet about the stages of end of life. This booklet offers information about the physiological and psychological changes that may occur in the actively dying patient. It offers strategies for families to help them identify and cope with these difficult symptoms. The booklet also discusses the process of grief and offers VA resources for the family after the patient dies. Most patients choose to spend their final days either at home or in hospice centers rather than the hospital. At this time, the PCCT coordinates with hospice agencies to facilitate a transition of care. Family meetings are arranged with PCCT, patient/family and the representative of the hospice agency. 


\section{Social and Spiritual Supports}

The LICSW provides much of the care in the psychological and social domains of palliative care. While the NP may prescribe medications that may alleviate some physical and psychologically distressing symptoms the LICSW employs non-medical interventions to support the patient and the family. She provides support through listening and coordinating services for the patient as both inpatient and with transitions of care to home or other settings. She identifies and reinforces positive coping mechanisms and may offer strategies to assist patient and family to facilitate learning new coping skills. The LICSW connects resources for the family in anticipation of their needs for assistance in caring for their loved one upon discharge.

The spiritual chaplain is pivotal in addressing the patient's needs for spiritual, religious and existential realms of palliative care. He visits the patient after the NP and LICSW see the patient and establishes some goals of care and symptom management. Initially, the spiritual chaplain asks permission to visit. If the patient grants permission the chaplain visits informally and then performs a formal intake assessment. He utilizes a VA approved tool, a variation of the HOPE spiritual assessment tool, to assess patient's spiritual status and needs (Anadarojah \& Hight, 2001). This tool helps to identify how the

patient perceives his spiritual or religious practices, sources of strengths and beliefs about life and after-life. If a patient refuses permission for chaplaincy visit, the spiritual counselor does not visit unless the patient requests a visit. While the chaplain does visit and offer spiritual counseling to people of all faiths, he reports that the VA population in this hospital is reflective of the general religious preferences of the state of Rhode Island. 
Approximately $55-60 \%$ of the patients identify themselves as Roman Catholic, $32 \%$ as a member of a Protestant denomination and the rest are categorized as other or no preference.

\section{Cultural Considerations}

There are several preferred preference identified by the NQF related to cultural components of care. The LICSW does identify unique cultural considerations in her intake assessment and continuing notes. The PCCT incorporates these cultural considerations into the patient's plan of care. The population of this VA hospital includes many Caucasians, African Americans and Hispanic veterans. Language is not typically a barrier as veterans are required to be English speaking in order to serve. The PCCT in this facility is an all Caucasian staff. The PCCT staff did acknowledge some racial barriers that may be perceived secondary to the lack of racial diversity.

An important and unique cultural component seen in the VA palliative care program is the culture of veterans. They are a population and culture within themselves. The culture may be varied depending upon the branch of service in which the veteran was enlisted. Additionally, the cultural variations may be related to the uniqueness of time and years of service as well as the experiences of war or combat that affect the veteran. The PCCT provides educational in-services to VA providers and to communities that service veterans outside the VA system about war specific considerations. While many veterans may be stoic, those veterans that have experienced post traumatic stress disorder often present with increased issues of trauma, pain, anxiety and sleep disturbances especially as the contend with their own end of life. The PTSD may compound the pain 
and anxiety in the palliative care patient. Other conditions that are seen in the veteran population are an increase in chronic depression and substance abuse. These conditions often complicate care and symptom management in the palliative care veteran. These and other mental health issues often create complex social circumstances and challenges in caring for the palliative care veteran.

\section{Legal and Ethical Concerns}

The NQF's has several preferred requirements that are in the realms of legal and ethical care of the patient. The medical ethics of autonomy, beneficence, non-malfecience and justice are strictly adhered to. In addition the principles of dignity, truth-telling and honesty are fundamental to the care of the palliative care patient. The VA follows all state and federal regulations regarding respecting legal rights of patients and families. They acknowledge early and often within the electronic record, the decision making capacity of the patient and the identified surrogate decision maker. The PCCT establishes early in treatment plan the patient's wishes and goals of care and works diligently to follow them. If the patient is no longer able to make decisions regarding care, the appointed surrogate decision maker is deferred to. The early involvement of PCCT and clearly defined goals of care make conflicts in care less likely as the patient's preference is documented repeatedly. There is an ethics committee within the VA hospital. As the number of palliative care consults has increased over the past 4 years, the ethics committee has had less referral for issues related to end of life care. In 2009 there was 1 referral, 2010 there were 4 cases and in 2011, 2012 and 2013 there were no referrals made to the ethics committee. 


\section{Death, Grief and Bereavement Care}

Lastly, the NQF specifies preferred practices related to active dying, death, treatment of the body and bereavement care. As most patients have expressed a preference to experience their last days of life in their own homes, most patients are discharged with home hospice referrals or hospice centers if they are near the actively dying stage. Occasionally, patients move quickly to the actively dying phase and are cared for in the acute care facility. The VA PCCT supports the patient and families by identifying this phase; providing education regarding the dying process and symptom management; and encouraging family presence. When possible, the VA places the patient in a private room to allow for privacy at this stage. They also place butterflies on the door of the patient's room to signify that this patient is in this phase in hopes to promote sensitivity to the family and their needs at this time. When the patient dies, the VA adheres to any religious or cultural customs that the family may have expressed within the scope of state and federal laws. The VA has a special flag quilt that is draped over the veteran's body and staff and or family escort the body to the morgue. Staff and visitors stop and salute the veteran as he passes in the hallway as a sign of respect and dignity for the fallen soldier.

The VA provides grief and bereavement information to the families. The office of decedent affairs contacts the family and provides information regarding benefits available through the VA such as financial and burial information. The spiritual counselor calls the family within 10 days of the veteran's death to express condolences to the family. Within one month, a sympathy card is sent to the bereaved family with information regarding the 
normal grief process as well as contact information of the Chaplain Service. At six months and at the one year anniversary, a call is made by the chaplain to monitor the grief process. The family is invited to remember their loved one at a semiannual interfaith memorial service at the VA. Should any family member be perceived to need care for complicated grief, he or she would be invited to a referral session which is intentionally designed to understand the measure of grief and refer the person to appropriate community resources.

\section{VA Internal Measures}

Some areas of internal measurement of the VA PCCT have seen significant improvement. In 2010, the total number of palliative care consults was 250 consults annually. This reflects a total number of patient deaths of 89,51 or $57.3 \%$ of who had a palliative care consult before their death. The trend has continued to improve over the past 3 years, which is the PCCT has continued to see more patients; there are less deaths in hospital and of those that die within the hospital there is a significantly higher percentage with the advantage of palliative care prior to death. In February 2013, the PCCT had seen 99 consults, there were 6 deaths within the facility, and this reflected an overall number of $85.71 \%$ of patients that died having experienced palliative care prior to their death.

\section{Team Members Perceived Strengths and Barriers to Care}

Another area of the evaluation that was not captured by the NQF's standards was the personal interviews of the staff members. The NP and LICSW both identified the time and presence that they were able to provide to the palliative care patients as an 
intangible benefit. They perceived that the trust established through the ongoing relationship with patients was highly valued and promoted quality care. They consistently identified the benefit of their team in providing honesty that promoted informed decision making in the palliative care patients and their families. Lastly, the team members identified critical interdisciplinary communication including family meetings and discussions regarding goals of care as one of the greatest benefits that the palliative care team provides

The PCCT identified some barriers to the provision of palliative care. While the VA has greatly endorsed and promoted palliative care, the team members still identify medical staff and the public misunderstanding of the scope and purpose of palliative care as a persistent barrier. Continual education of both the medical staff and public is still necessary to maximize the use and benefit of palliative care programs. The staff also acknowledged that additional staff members such as an additional NP would be an incredible benefit in reducing the workload of the team and enhancing the services they would be able to provide. Financial constraints within the federal system prevent this additional staff at the present time.

The following table illustrates the NQF's stated preferred practices, the practice of palliative care at the VA facility and the documentation of evidence of the stated practice. The bolded words are the words from the NQF standards. The CDC Framework for program evaluation was utilized as the theoretical framework in the approach for evaluation. It is a practical approach to evaluation with organized steps and standards for evaluation. 
Table 1

\begin{tabular}{|c|c|c|}
\hline Preferred Practices & Practice at VA & Evidence \\
\hline $\begin{array}{l}\text { 1. Provide palliative and } \\
\text { hospice care by an } \\
\text { interdisciplinary team } \\
\text { of skilled palliative care } \\
\text { professionals, including, } \\
\text { for example, physicians, } \\
\text { nurses, social workers, } \\
\text { pharmacists, spiritual } \\
\text { care counselors, and } \\
\text { others who collaborate } \\
\text { with primary healthcare } \\
\text { professional(s). }\end{array}$ & 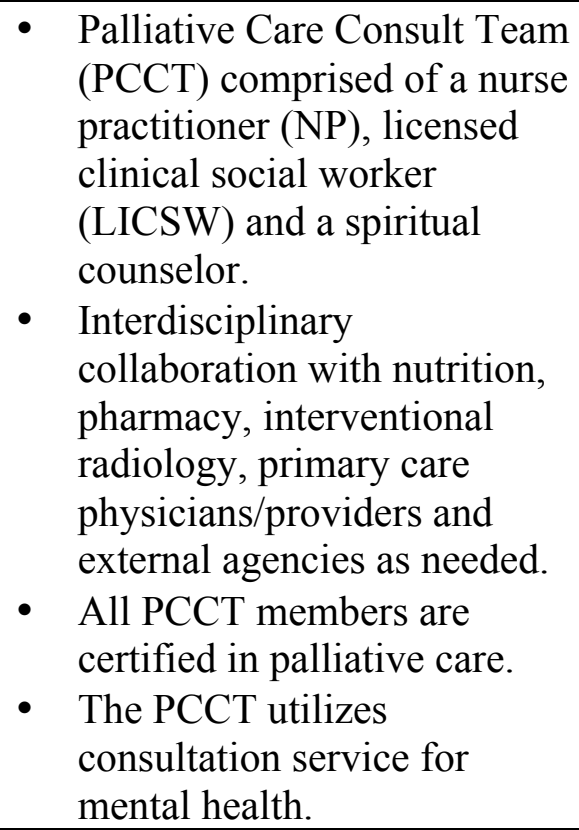 & $\begin{array}{l}\text { VHA Directive } \\
\text { 2008-066. }\end{array}$ \\
\hline $\begin{array}{l}\text { 2. Provide access to } \\
\text { palliative and hospice } \\
\text { care that is responsive to } \\
\text { the patient and family } \mathbf{2 4} \\
\text { hours a day, } 7 \text { days a } \\
\text { week. }\end{array}$ & $\begin{array}{l}\text { - PCCT available Monday } \\
\text { through Friday 7:00 am to } \\
\text { 4:00 pm. for inpatient } \\
\text { consults. } \\
\text { - PCCT available } 24 / 7 \text { via } \\
\text { telephone for emergencies or } \\
\text { as a resource. Team } \\
\text { members come in to the } \\
\text { hospital off hours for } \\
\text { emergencies that cannot be } \\
\text { managed by phone. } \\
\text { Vacations covered by } \\
\text { outpatient palliative care } \\
\text { specialists; specialty specific. } \\
\text { *An innovative approach is } \\
\text { Nurse Champions that have } \\
\text { additional training in } \\
\text { palliative care are on each } \\
\text { unit. } \\
\text { *Palliative Care symptom } \\
\text { management resource book } \\
\text { for residents on call }\end{array}$ & $\begin{array}{l}\text { - } \quad \text { VHA Directive } \\
\text { 2008-066. } \\
\text { - } \text { Nurse Champions, } \\
\text { training-role } \\
\text { - On-call Provider } \\
\text { Handbook for } \\
\text { Palliative Care } \\
\text { Patients } \\
\text { publication. } \\
\text { The number of } \\
\text { PCCT consults in } \\
\text { the VA has } \\
\text { increased. } \\
\text { 2010- } 250 \text { pts. } \\
\text { 2011-392 pts. } \\
\text { 2012- } 356 \text { pts. } \\
\text { The \% of deaths } \\
\text { with PCCT is } \\
\text { above } 75 \% \text { since } \\
\text { 2011 (VA goal). }\end{array}$ \\
\hline
\end{tabular}




\begin{tabular}{|c|c|c|}
\hline Preferred Practices & Practice at VA & Evidence \\
\hline $\begin{array}{l}\text { 3. Provide continuing } \\
\text { education to all } \\
\text { healthcare professionals } \\
\text { on the domains of } \\
\text { palliative care and } \\
\text { hospice care. }\end{array}$ & $\begin{array}{l}\text { - Monthly in-services to } \\
\text { medicine and nursing. } \\
\text { Encourage ELNET (End of } \\
\text { Life Nursing Education } \\
\text { Training) to nursing staff. } \\
\text { - PCCT provides presentations } \\
\text { regarding palliative care to } \\
\text { PCP, community } \\
\text { organizations, hospitals and } \\
\text { agencies within the } \\
\text { community. } \\
\text { Palliative care committee } \\
\text { meets monthly to assess } \\
\text { issues and identify learning } \\
\text { needs within the facility and } \\
\text { other QI initiatives } \\
\text { On-line in-services and } \\
\text { webinars available to staff. } \\
\text { New staff orientation } \\
\text { includes a module (or } \\
\text { section) regarding PCCT }\end{array}$ & $\begin{array}{ll}\text { - } & \text { In-service } \\
\text { documentation. } \\
\text { - } & \text { ELNET modules. } \\
\text { The director of } \\
\text { PCCT provided } 3 \\
\text { seminars in past } \\
\text { 3months to } \\
\text { nursing, other } \\
\text { hospitals/agencies } \\
\text { to share Best } \\
\text { practices. } \\
\text { Palliative care } \\
\text { committees notes, } \\
\text { observation of } \\
\text { meetings. }\end{array}$ \\
\hline 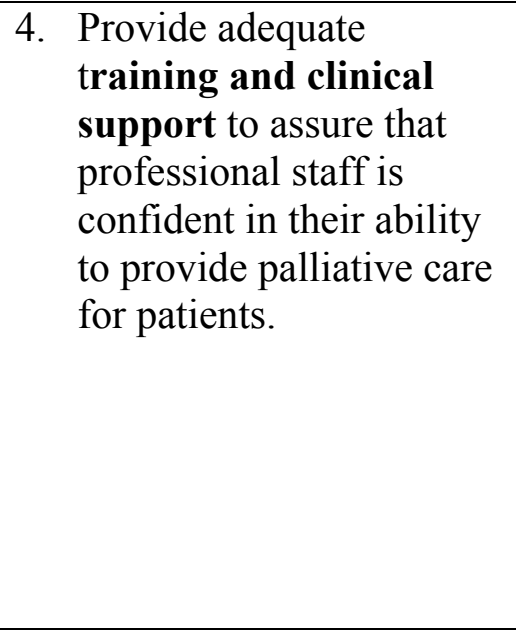 & $\begin{array}{l}\text { PCCT consults with medicine } \\
\text { residents and nursing for } \\
\text { issues around palliation. } \\
\text { - Debriefing for difficult cases } \\
\text { on the units. } \\
\text { - Surveys staff to identify areas } \\
\text { of needed training and tailor } \\
\text { educational programs. }\end{array}$ & $\begin{array}{l}\text { - In-services to new } \\
\text { residents with } \\
\text { resource guides } \\
\text { such as, On-call } \\
\text { Provider } \\
\text { Handbookfor } \\
\text { Palliative Care } \\
\text { Patients, } \\
\text { Communication } \\
\text { Phrases in } \\
\text { Palliative Care, } \\
\text { and PCCT staff } \\
\text { interviews. } \\
\end{array}$ \\
\hline $\begin{array}{l}\text { 5. Hospice care and } \\
\text { specialized palliative } \\
\text { care professionals should } \\
\text { be appropriately trained, } \\
\text { credentialed, and/or } \\
\text { certified in their area of } \\
\text { expertise }\end{array}$ & $\begin{array}{ll}\text { - } & \text { ELNEC( End of Life Nursing } \\
\text { Consortium) } \\
\text { - } \text { CELC (VA Comprehensive } \\
\text { End of Life Care. } \\
\text { - EPEC (education on } \\
\text { Palliative and End of Life } \\
\text { Care) }\end{array}$ & $\begin{array}{l}\text { Program and } \\
\text { curricula in PCCT } \\
\text { office for each of } \\
\text { these programs. }\end{array}$ \\
\hline
\end{tabular}




\begin{tabular}{|c|c|c|}
\hline Preferred Practices & Practice at VA & Evidence \\
\hline $\begin{array}{l}\text { 6. Formulate, utilize, and } \\
\text { regularly review a timely } \\
\text { care plan based on a } \\
\text { comprehensive } \\
\text { interdisciplinary } \\
\text { assessment of the values, } \\
\text { preferences, goals, and } \\
\text { needs of the patient and } \\
\text { family and, to the extent } \\
\text { that existing privacy laws } \\
\text { permit, ensure that the } \\
\text { plan is broadly } \\
\text { disseminated, both } \\
\text { internally and externally, } \\
\text { to all professionals } \\
\text { involved in the patient's } \\
\text { care. }\end{array}$ & $\begin{array}{l}\text { The PCCT responds to } \\
\text { consults on the day they are } \\
\text { received or at the maximum } \\
\text { within } 24 \text { hours of referral. } \\
\text { Thorough intake assessment } \\
\text { completed. It includes } \\
\text { physical assessment, medical } \\
\text { course, social history, } \\
\text { clarification of goals of care, } \\
\text { need for symptom } \\
\text { management, decision } \\
\text { making capacity, spiritual } \\
\text { preferences, financial issues, } \\
\text { functional ability, cognition, } \\
\text { psychological or emotional } \\
\text { issues, coping status and } \\
\text { systems of support and code } \\
\text { status. } \\
\text { Assessment documented in } \\
\text { an electronic record for } \\
\text { internal use and may be } \\
\text { released to outside facilities } \\
\text { or agencies as appropriate for } \\
\text { patient care. }\end{array}$ & $\begin{array}{l}\text { - } \\
\text { PCCT stated } \\
\text { practice } \\
\text { (Confirmed by } \\
\text { chart audit). } \\
\text { - Chart audit. } \\
\text { - Intake assessment } \\
\text { forms of NP, } \\
\text { LICSW and } \\
\text { spiritual } \\
\text { assessment. }\end{array}$ \\
\hline $\begin{array}{l}\text { 7. Ensure that upon transfer } \\
\text { between healthcare } \\
\text { settings, there is timely } \\
\text { and thorough } \\
\text { communication of the } \\
\text { patient's goals, } \\
\text { preferences, values, and } \\
\text { clinical information so } \\
\text { that continuity of care } \\
\text { and seamless follow-up } \\
\text { are assured. }\end{array}$ & $\begin{array}{l}\text { Electronic record is a strong } \\
\text { communication tool within } \\
\text { VA (real time accessibility } \\
\text { from any VA provider). } \\
\text { Phone/ verbal report with } \\
\text { opportunity to clarify any } \\
\text { questions is included in all } \\
\text { changes of level of care. } \\
\text { Patient/family meetings occur } \\
\text { within facility and inter- } \\
\text { facility to assist in transitions } \\
\text { of care } \\
\text { Always occur when transition } \\
\text { to hospice. } \\
\text { Close coordination between } \\
\text { PCCT and outpatient services } \\
\text { or outside agencies. }\end{array}$ & $\begin{array}{ll}\text { - } & \text { Electronic patient } \\
\text { record. } \\
\text { - } \text { Interagency } \\
\text { electronic } \\
\text { documentation. } \\
\text { - } \text { Observation. } \\
\text { - } \text { There are informal } \\
\text { relationships with } \\
\text { outside agencies } \\
\text { as VA does not } \\
\text { allow for } \\
\text { contractual } \\
\text { arrangements } \\
\text { (staff interview). }\end{array}$ \\
\hline
\end{tabular}




\begin{tabular}{|c|c|c|}
\hline Preferred Practices & Practice at VA & Evidence \\
\hline $\begin{array}{l}\text { 8. Healthcare professionals } \\
\text { should present hospice } \\
\text { as an option to all } \\
\text { patients and families } \\
\text { when death within a year } \\
\text { would not be surprising } \\
\text { and should reintroduce } \\
\text { the hospice option as the } \\
\text { patient declines. }\end{array}$ & $\begin{array}{l}\text { - The PCCT includes hospice } \\
\text { as an option in the initial } \\
\text { evaluation and when the } \\
\text { patient's trajectory changes } \\
\text { and hospice is an appropriate } \\
\text { option. } \\
\text { - During first initial } \\
\text { conversations, several } \\
\text { treatment options are } \\
\text { delineated including that } \\
\text { some people choose hospice } \\
\text { if appropriate for them. } \\
\end{array}$ & $\begin{array}{ll}\text { - } & \text { Chart audit } \\
\text { - } & \text { Observation. }\end{array}$ \\
\hline $\begin{array}{l}\text { 9. Patients and caregivers } \\
\text { should be asked by } \\
\text { palliative and hospice } \\
\text { care programs to assess } \\
\text { physicians'/healthcare } \\
\text { professionals' ability to } \\
\text { discuss hospice as an } \\
\text { option. }\end{array}$ & $\begin{array}{l}\text { - All PCCT referrals are } \\
\text { ordered by a LIP but may be } \\
\text { triggered by nursing } \\
\text { assessment. } \\
\text { - After the consultation with } \\
\text { patient, PCCT meets with the } \\
\text { medical team- to coordinate } \\
\text { and integrate plan of care. } \\
\text { - Hospice is introduced as an } \\
\text { option: palliative care team } \\
\text { very skilled in these } \\
\text { discussions. }\end{array}$ & $\begin{array}{l}\text { Internal Policy } \\
\text { VHA directive } \\
\text { 2008-066. } \\
\text { PCCT provides } \\
\text { handouts and } \\
\text { instructional } \\
\text { assistance to new } \\
\text { residents and } \\
\text { providers. }\end{array}$ \\
\hline $\begin{array}{l}\text { 10. Enable patients to } \\
\text { make informed } \\
\text { decisions about their } \\
\text { care by educating them } \\
\text { on the process of their } \\
\text { disease, prognosis, and } \\
\text { the benefits and burdens } \\
\text { of potential } \\
\text { interventions. }\end{array}$ & $\begin{array}{l}\text { The PCCT assesses patient's } \\
\text { understanding of their disease } \\
\text { process, trajectory of illness, } \\
\text { prognosis, goals of care and } \\
\text { their capacity for decision } \\
\text { making. } \\
\text { Meetings will be scheduled } \\
\text { with patient and medical team } \\
\text { to provide clarification about } \\
\text { medical prognosis, burden of } \\
\text { treatment, treatment options } \\
\text { so that patients may make } \\
\text { informed decisions. Multi- } \\
\text { disciplinary meetings are } \\
\text { scheduled in complex cases, } \\
\text { if family or staff believe there } \\
\text { is need for increased }\end{array}$ & 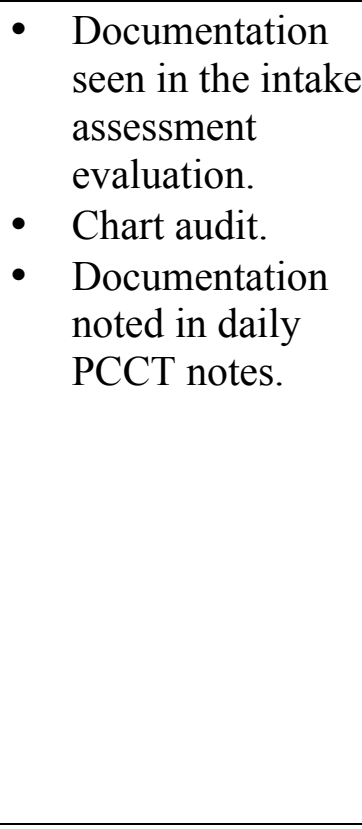 \\
\hline
\end{tabular}




\begin{tabular}{|c|c|c|}
\hline Preferred Practices & Practice at VA & Evidence \\
\hline & $\begin{array}{l}\text { clarification or a major } \\
\text { change in the goal of care., } \\
\text { i.e. comfort or hospice rather } \\
\text { than aggressive treatment. }\end{array}$ & \\
\hline $\begin{array}{l}\text { 11. Provide education and } \\
\text { support to families and } \\
\text { unlicensed caregivers } \\
\text { based on the patient's } \\
\text { individualized care plan } \\
\text { to assure safe and } \\
\text { appropriate care for the } \\
\text { patient. }\end{array}$ & 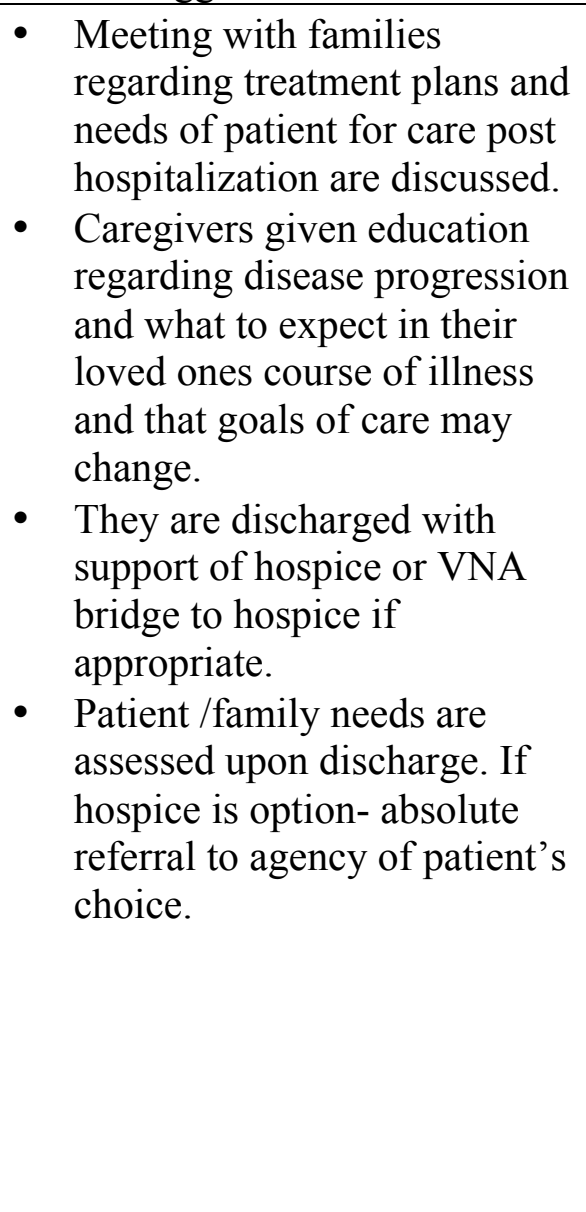 & $\begin{array}{l}\text { - VA has brochure } \\
\text { introducing } \\
\text { Palliative care. } \\
\text { VA gives a book, } \\
\text { Palliative Care } \\
\text { Family Handbook, } \\
\text { to assist in } \\
\text { education. } \\
\text { Handouts are } \\
\text { given to patients } \\
\text { and families to } \\
\text { understand illness } \\
\text { and expected } \\
\text { course of illness. } \\
\text { Management of } \\
\text { s/s of illness and } \\
\text { side effects given } \\
\text { to family. } \\
\text { Hard Choices for } \\
\text { Loving People - a } \\
\text { booklet discussing } \\
\text { treatment options } \\
\text { including artificial } \\
\text { nutrition and } \\
\text { comfort care. }\end{array}$ \\
\hline $\begin{array}{l}\text { 12. Measure and document } \\
\text { pain, dsypnea, } \\
\text { constipation, and other } \\
\text { symptoms using } \\
\text { available standardized } \\
\text { scales. }\end{array}$ & $\begin{array}{l}\text { PCCT measures symptoms } \\
\text { with Condensed Memorial } \\
\text { Assessment Scale (CMAS), a } \\
\text { likert scale that addresses } 14 \\
\text { common symptoms at end of } \\
\text { life. } \\
\text { - } \text { Karnofsky scale used. } \\
\text { - Bedside nurse assesses pain } \\
\text { at least q shift with } \\
\text { standardize tool. }\end{array}$ & $\begin{array}{ll}\text { - } & \text { Chart audit. } \\
\text { - } & \text { Pain Intensity } \\
& \text { Scales }\end{array}$ \\
\hline
\end{tabular}




\begin{tabular}{|c|c|c|}
\hline Preferred Practices & Practice at VA & Evidence \\
\hline $\begin{array}{l}\text { 13. Assess and manage } \\
\text { symptoms and side } \\
\text { effects in a timely, safe, } \\
\text { and effective manner to a } \\
\text { level that is acceptable to } \\
\text { the patient and family }\end{array}$ & $\begin{array}{l}\text { Initial consult by PCCT } \\
\text { within } 24 \text { hours of order. } \\
\text { Daily rounds on all in-patient } \\
\text { palliative care patients. If } \\
\text { poorly controlled symptoms; } \\
\text { they are revisited that day. } \\
\text { - } \text { No established formal } \\
\text { process to measure patient } \\
\text { satisfaction of acute symptom } \\
\text { management. } \\
\text { A bereaved family survey for } \\
\text { all patients hospitalized for } \\
\text { their last month of life. It } \\
\text { addresses many of the } \\
\text { concerns at end of life care. }\end{array}$ & 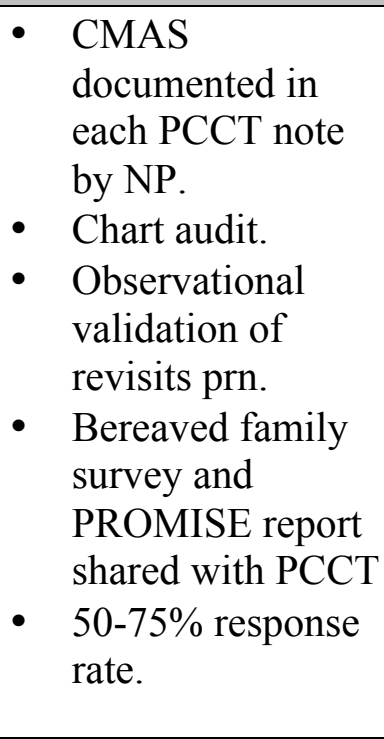 \\
\hline $\begin{array}{l}\text { 14. Measure and document } \\
\text { anxiety, depression, } \\
\text { delirium, behavioral } \\
\text { disturbances, and other } \\
\text { common psychological } \\
\text { symptoms using } \\
\text { available standardized } \\
\text { scales. }\end{array}$ & $\begin{array}{l}\text { CMAS, used by PCCT, } \\
\text { measures symptoms of } \\
\text { anxiety, depression and } \\
\text { insomnia. } \\
\text { - VA practice does not use a } \\
\text { validated tool to assess } \\
\text { delirium. } \\
\text { - Psychiatry referrals are made } \\
\text { for patients with complex } \\
\text { behavioral symptoms or early } \\
\text { on in illness if co-morbidity. } \\
\text { The bedside nurse does not } \\
\text { have a validated tool to } \\
\text { measure these signs and } \\
\text { symptoms seen in the } \\
\text { palliative care patient except } \\
\text { for pain. }\end{array}$ & $\begin{array}{ll}\text { - } & \text { Chart audit } \\
\text { - } & \text { Interviews with } \\
\text { members of } \\
\text { PCCT. }\end{array}$ \\
\hline $\begin{array}{l}\text { 15. Manage anxiety, } \\
\text { depression, delirium, } \\
\text { behavioral disturbances } \\
\text { and other common } \\
\text { psychological symptoms } \\
\text { in a timely, safe, and } \\
\text { effective manner to a } \\
\text { level that is acceptable to } \\
\text { the patient and family. }\end{array}$ & $\begin{array}{l}\text { - The PCCT utilizes the CMAS } \\
\text { and recommended algorithms } \\
\text { and protocols for symptom } \\
\text { management. } \\
\text { Referrals are made to } \\
\text { psychiatry to assist } \\
\text { management of complex } \\
\text { depression ,delirium or } \\
\text { behavioral disturbances }\end{array}$ & $\begin{array}{ll}\text { - } & \text { Chart audits. } \\
\text { - Interview with } \\
\text { staff. } \\
\text { - Observation of } \\
\text { Psychiatric } \\
\text { consultation. }\end{array}$ \\
\hline
\end{tabular}




\begin{tabular}{|c|c|c|}
\hline Preferred Practices & Practice at VA & Evidence \\
\hline $\begin{array}{l}\text { 16. Assess and manage the } \\
\text { psychological reactions } \\
\text { of patients and families } \\
\text { (including stress, } \\
\text { anticipatory grief, and } \\
\text { coping) in a regular, } \\
\text { ongoing fashion in order } \\
\text { to address emotional and } \\
\text { functional impairment } \\
\text { and loss. }\end{array}$ & $\begin{array}{l}\text { - LICSW does a full } \\
\text { assessment of patient and } \\
\text { family psychosocial issues, } \\
\text { needs, coping styles, coping } \\
\text { status, QOL, and support } \\
\text { systems. } \\
\text { - LICSW offers support and } \\
\text { strategies to support patient } \\
\text { and families. } \\
\text { CMAS assesses anxiety, } \\
\text { stress and insomnia. } \\
\text { Grief and bereavement } \\
\text { support groups are introduced } \\
\text { to family. }\end{array}$ & $\begin{array}{l}\text { - } \quad \text { Chart audit. } \\
\text { Handouts and } \\
\text { referrals for grief } \\
\text { and support } \\
\text { groups for family. }\end{array}$ \\
\hline $\begin{array}{l}\text { 17. Develop and offer a grief } \\
\text { and bereavement care } \\
\text { plan to provide services } \\
\text { to patients and families } \\
\text { prior to and for at least } \\
13 \text { months after the death } \\
\text { of the patient. }\end{array}$ & 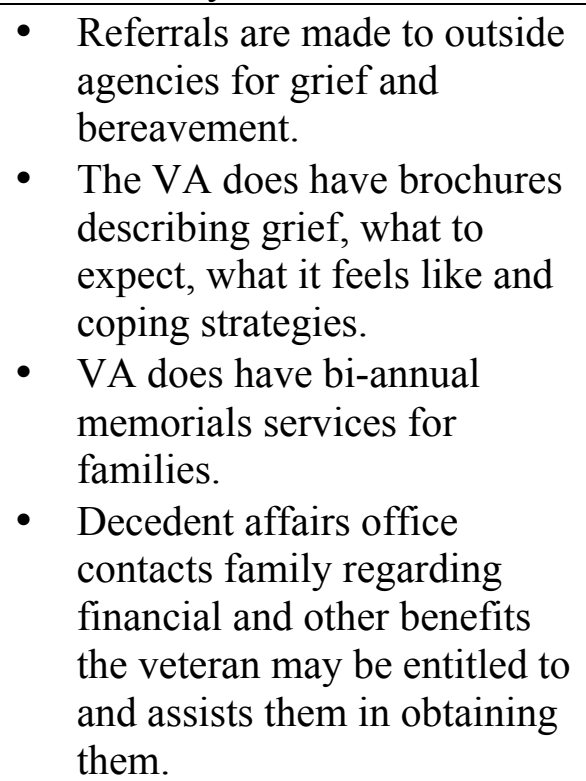 & $\begin{array}{l}\text { When you are } \\
\text { grieving - VA } \\
\text { booklet. } \\
\text { - Grief support } \\
\text { groups at outside } \\
\text { facilities via } \\
\text { flyers. } \\
\text { Interfaith service } \\
\text { of remembrance } \\
\text { written program. } \\
\text { PCCT interviews. } \\
\text { Observation at } \\
\text { Palliative care } \\
\text { committee } \\
\text { meetings. }\end{array}$ \\
\hline $\begin{array}{l}\text { 18. Conduct regular patient } \\
\text { and family care } \\
\text { conferences with } \\
\text { physicians and other } \\
\text { appropriate members of } \\
\text { the interdisciplinary team } \\
\text { to provide information, } \\
\text { to discuss goals of care, } \\
\text { disease prognosis, and } \\
\text { advance care planning, } \\
\text { and to offer support. }\end{array}$ & $\begin{array}{l}\text { PCCT coordinates } \\
\text { interdisciplinary and } \\
\text { patient/family meetings for } \\
\text { discussion of disease } \\
\text { prognosis, identifying goals } \\
\text { of care, care planning and } \\
\text { advance plans of care. } \\
\text { They also include outside } \\
\text { supportive care agencies as } \\
\text { appropriate. }\end{array}$ & $\begin{array}{ll}\text { - } & \text { Chart audits. } \\
\text { - } & \text { Staff interviews. } \\
\text { - } & \text { Daily discharge } \\
\text { rounds on all } \\
\text { patients } \\
\text { (multidisciplinary) } \\
\text {. }\end{array}$ \\
\hline
\end{tabular}




\begin{tabular}{|c|c|c|}
\hline Preferred Practices & Practice at VA & Evidence \\
\hline $\begin{array}{l}\text { 19. Develop and implement } \\
\text { a comprehensive social } \\
\text { care plan that addresses } \\
\text { the social, practical, and } \\
\text { legal needs of the patient } \\
\text { and caregivers, including } \\
\text { but not limited to } \\
\text { relationships, } \\
\text { communication, existing } \\
\text { social and cultural } \\
\text { networks, decision } \\
\text { making, work and school } \\
\text { settings, finances, } \\
\text { sexuality/intimacy, } \\
\text { caregiver } \\
\text { availability/stress, and } \\
\text { access to medicines and } \\
\text { equipment. }\end{array}$ & $\begin{array}{l}\text { LICSW intake assessment } \\
\text { and continuing assessments } \\
\text { help patient and families with } \\
\text { issues of social, financial, } \\
\text { practical, legal issues such as } \\
\text { advance directives, } \\
\text { - Pt made be discharged and } \\
\text { transitioned to home based } \\
\text { primary care which will } \\
\text { increase the resources } \\
\text { available to patient and } \\
\text { family. There is Home Based } \\
\text { Primary Care, palliative care } \\
\text { team as well to serve the } \\
\text { patient in the community. }\end{array}$ & $\begin{array}{ll}\text { - } & \text { Chart audit } \\
\text { - } & \text { Observation of } \\
\text { daily rounds }\end{array}$ \\
\hline $\begin{array}{l}\text { 20. Develop and document a } \\
\text { plan based on an } \\
\text { assessment of religious, } \\
\text { spiritual, and } \\
\text { existential concerns } \\
\text { using a structured } \\
\text { instrument, and integrate } \\
\text { the information obtained } \\
\text { from the assessment into } \\
\text { the palliative care plan. }\end{array}$ & $\begin{array}{l}\text { The spiritual counselor } \\
\text { performs an intake spiritual } \\
\text { assessment after the patient is } \\
\text { evaluated by the PCCT. } \\
\text { Assessment of patients' } \\
\text { religious, spiritual practices } \\
\text { and preferences are } \\
\text { recognized as well as any } \\
\text { existential concerns that the } \\
\text { patient may have. } \\
\text { Assessment shared with the } \\
\text { healthcare team via the } \\
\text { electronic document and in } \\
\text { daily interdisciplinary plans }\end{array}$ & $\begin{array}{ll} & \text { Chart audit. } \\
\text { - } & \text { Spiritual } \\
& \text { assessment tool. }\end{array}$ \\
\hline $\begin{array}{l}\text { 21. Provide information } \\
\text { about the availability of } \\
\text { spiritual care services, } \\
\text { and make spiritual care } \\
\text { available either through } \\
\text { organizational spiritual } \\
\text { care counseling or } \\
\text { through the patient's own } \\
\text { clergy relationships. }\end{array}$ & $\begin{array}{l}\text { - Spiritual care is available on } \\
\text { call } 24 / 7 \\
\text { Non-denominational spiritual } \\
\text { services are available to all } \\
\text { patients as well as } \\
\text { communication with patient's } \\
\text { own clergy if desired. } \\
\text { Written tools are faith } \\
\text { specific. }\end{array}$ & $\begin{array}{l}\text { - Chart audit. } \\
\text { Written literature } \\
\text { i.e., Bible, Koran, } \\
\text { Book of Mormon, } \\
\text { Positive Thinking } \\
\text { Pamphlets, } \\
\text { Guideposts for } \\
\text { pts. and visitors. }\end{array}$ \\
\hline
\end{tabular}




\begin{tabular}{|c|c|c|}
\hline Preferred Practices & Practice at VA & Evidence \\
\hline $\begin{array}{l}\text { 22. Specialized palliative and } \\
\text { hospice care teams } \\
\text { should include spiritual } \\
\text { care professionals } \\
\text { appropriately trained and } \\
\text { certified in palliative } \\
\text { care. }\end{array}$ & 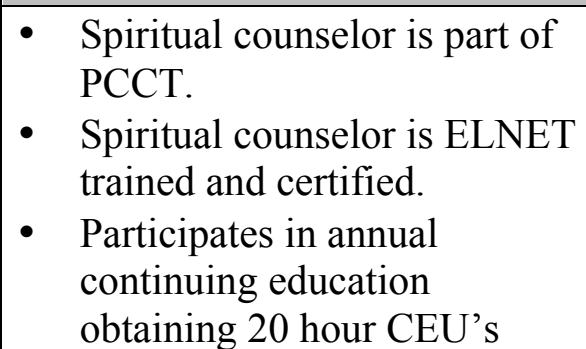 & $\begin{array}{ll} & \text { Chart audit. } \\
\text { - } & \text { Observation. } \\
\text { - } & \text { Records in PCCT } \\
\text { office. }\end{array}$ \\
\hline $\begin{array}{l}\text { 23. Specialized palliative and } \\
\text { hospice spiritual care } \\
\text { professionals should } \\
\text { build partnerships with } \\
\text { community clergy and } \\
\text { provide education and } \\
\text { counseling related to } \\
\text { end-of-life care. }\end{array}$ & 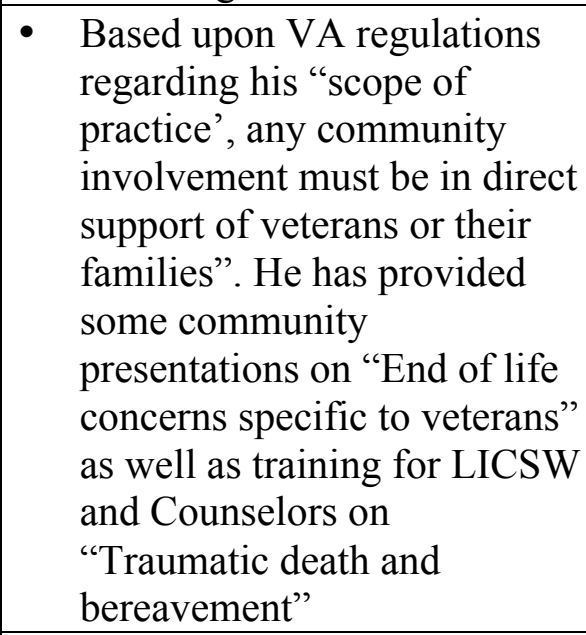 & - Interview. \\
\hline $\begin{array}{l}\text { 24. Incorporate cultural } \\
\text { assessment as a } \\
\text { component of } \\
\text { comprehensive palliative } \\
\text { and hospice care } \\
\text { assessment, including but } \\
\text { not limited to locus of } \\
\text { decision making, } \\
\text { preferences regarding } \\
\text { disclosure of } \\
\text { information, truth telling } \\
\text { and decision making, } \\
\text { dietary preferences, } \\
\text { language, family } \\
\text { communication, desire } \\
\text { for support measures } \\
\text { such as palliative } \\
\text { therapies and } \\
\text { complementary and } \\
\text { alternative medicine, } \\
\text { perspectives on death, }\end{array}$ & $\begin{array}{l}\text { The Primary medical } \\
\text { provider is the person who } \\
\text { gives information about } \\
\text { illness, prognosis and disease } \\
\text { trajectory. } \\
\text { Family meetings often } \\
\text { explore cultural beliefs about } \\
\text { truth telling; moral and } \\
\text { ethical implications are } \\
\text { explained and discussed with } \\
\text { family members (Pt has right } \\
\text { and moral obligation to } \\
\text { provide truth). } \\
\text { VA supports alternative } \\
\text { therapies such as REIKI, } \\
\text { music therapy and is } \\
\text { supportive of anything non- } \\
\text { harmful to patient that pt or } \\
\text { family endorses. } \\
\text { Complementary alternative } \\
\text { therapies are encouraged if }\end{array}$ & $\begin{array}{l}\text { - Observation of } \\
\text { family meetings. } \\
\text { - Chart audit. } \\
\text { - Interviews with } \\
\text { PCCT staff. }\end{array}$ \\
\hline
\end{tabular}




\begin{tabular}{|c|c|c|}
\hline Preferred Practices & Practice at VA & Evidence \\
\hline $\begin{array}{l}\text { suffering, and grieving, } \\
\text { and funeral/burial rituals. }\end{array}$ & patient or family preferred. & \\
\hline $\begin{array}{l}\text { 25. Provide professional } \\
\text { interpreter services and } \\
\text { culturally sensitive } \\
\text { materials in the patient's } \\
\text { and family's preferred } \\
\text { language. }\end{array}$ & 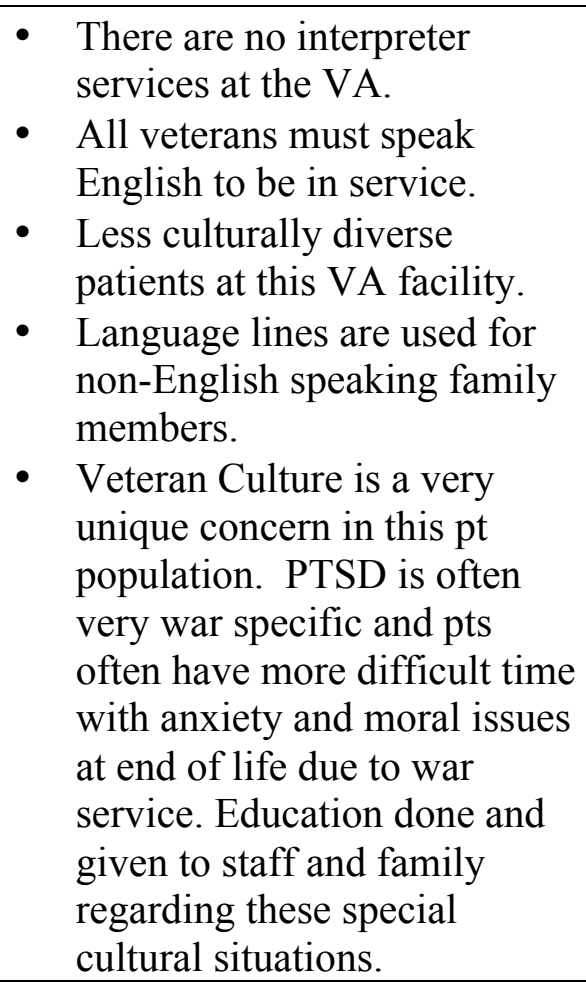 & $\begin{array}{ll}\text { - } & \text { Interviews with } \\
\text { PCCT staff. } \\
\text { - } \text { In-service on war } \\
\text { specific PTSD and } \\
\text { impact on end of } \\
\text { life issues. }\end{array}$ \\
\hline $\begin{array}{l}\text { 26. Recognize and } \\
\text { document the transition } \\
\text { to the active dying } \\
\text { phase, and communicate } \\
\text { to the patient, family, and } \\
\text { staff the expectation of } \\
\text { imminent death. }\end{array}$ & $\begin{array}{l}\text { Because most palliative care } \\
\text { patients do not wish to spend } \\
\text { end of life in the acute care } \\
\text { hospital, they are usually } \\
\text { transferred to home with } \\
\text { hospice, hospice facility or } \\
\text { skilled nursing home with } \\
\text { hospice service. } \\
\text { If patient progresses to active } \\
\text { dying phase in the hospital, } \\
\text { the patient is moved to a } \\
\text { private room. They utilize } \\
\text { butterflies on the door so all } \\
\text { staff are aware that a patient } \\
\text { is at End of life and will be } \\
\text { respectful and supportive. } \\
\text { Aggressive symptom } \\
\text { management and family } \\
\text { support becomes the focus. }\end{array}$ & $\begin{array}{l}\text { - VA booklet } \\
\text { Palliative care } \\
\text { Family Handbook. } \\
\text { - Observation. } \\
\text { - Chart audit. }\end{array}$ \\
\hline
\end{tabular}




\begin{tabular}{|c|c|c|}
\hline Preferred Practices & Practice at VA & Evidence \\
\hline $\begin{array}{l}\text { 27. Educate the family on a } \\
\text { timely basis regarding } \\
\text { the signs and symptoms } \\
\text { of imminent death in an } \\
\text { age-appropriate, } \\
\text { developmentally } \\
\text { appropriate, and } \\
\text { culturally appropriate } \\
\text { manner. }\end{array}$ & $\begin{array}{l}\text { - Family provided a brochure } \\
\text { regarding stages of disease } \\
\text { progression, signs and } \\
\text { symptoms associated with } \\
\text { end of life. } \\
\text { - Families are supported and } \\
\text { verbally educated regarding } \\
\text { imminent death by PCT, } \\
\text { medical and nursing staff in } \\
\text { acute care hospital. }\end{array}$ & $\begin{array}{l}\text { - VA booklet } \\
\text { Palliative care } \\
\text { family Handbook. } \\
\text { - Observation. } \\
\text { - Chart audit. }\end{array}$ \\
\hline $\begin{array}{l}\text { 28. As part of the ongoing } \\
\text { care planning process, } \\
\text { routinely ascertain and } \\
\text { document patient and } \\
\text { family wishes about the } \\
\text { care setting for the site of } \\
\text { death, and fulfill patient } \\
\text { and family preferences } \\
\text { when possible. }\end{array}$ & $\begin{array}{l}\text { Documentation of the patient } \\
\text { and family wishes regarding } \\
\text { care and location for side of } \\
\text { death is discussed in PCCT } \\
\text { intake assessment or when } \\
\text { patient transitions to hospice } \\
\text { level of care. All efforts are } \\
\text { made to accommodate patient } \\
\text { and family preferences and } \\
\text { when not able, PCCT meets } \\
\text { with pt/family offers support } \\
\text { and most satisfactory } \\
\text { alternative. }\end{array}$ & $\begin{array}{ll}\text { - } & \text { Chart audits. } \\
\text { - } & \text { Observation. } \\
\text { - } & \text { Discharge rounds. }\end{array}$ \\
\hline $\begin{array}{l}\text { 29. Provide adequate } \\
\text { dosage of analgesics } \\
\text { and sedatives as } \\
\text { appropriate to achieve } \\
\text { patient comfort during } \\
\text { the active dying phase, } \\
\text { and address concerns and } \\
\text { fears about using } \\
\text { narcotics and of } \\
\text { analgesics hastening } \\
\text { death. }\end{array}$ & 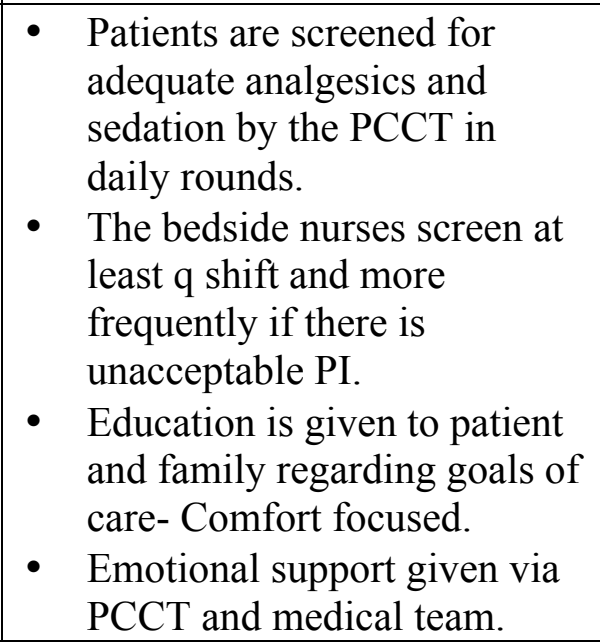 & $\begin{array}{l}\text { - } \text { VA brochure on } \\
\text { Palliative Care } \\
\text { Family Handbook } \\
\text { - Chart audit } \\
\text { - On- call Provider } \\
\text { Handbook with } \\
\text { pain management } \\
\text { guidelines } \\
\text { including equi- } \\
\text { analgesic dosing. } \\
\text { Observations. }\end{array}$ \\
\hline $\begin{array}{l}\text { 30. Treat the body after } \\
\text { death with respect } \\
\text { according to the cultural } \\
\text { and religious practices of } \\
\text { the family and in }\end{array}$ & $\begin{array}{l}\text { - The body is treated with } \\
\text { respect. Any cultural or } \\
\text { religious practices are abided } \\
\text { by if possible. } \\
\text { - The body is brought to }\end{array}$ & $\begin{array}{l}\text { - Observation at a } \\
\text { PCCT committee } \\
\text { meeting. They } \\
\text { are working on } \\
\text { new policy that }\end{array}$ \\
\hline
\end{tabular}




\begin{tabular}{|c|c|c|}
\hline Preferred Practices & Practice at VA & Evidence \\
\hline $\begin{array}{l}\text { accordance with local } \\
\text { law. }\end{array}$ & $\begin{array}{l}\text { morgue by honor guard (may } \\
\text { be family, nurses or } \\
\text { transport), draped in military } \\
\text { flag quilt. Staff salutes the } \\
\text { veteran as the body passes. }\end{array}$ & $\begin{array}{l}\text { makes practice a } \\
\text { written policy. } \\
\text { Interviews with } \\
\text { PCCT staff and } \\
\text { bedside nursing. }\end{array}$ \\
\hline $\begin{array}{l}\text { 31. Facilitate effective } \\
\text { grieving by } \\
\text { implementing in a timely } \\
\text { manner a bereavement } \\
\text { care plan after the } \\
\text { patient's death, when the } \\
\text { family remains the focus } \\
\text { of care. }\end{array}$ & 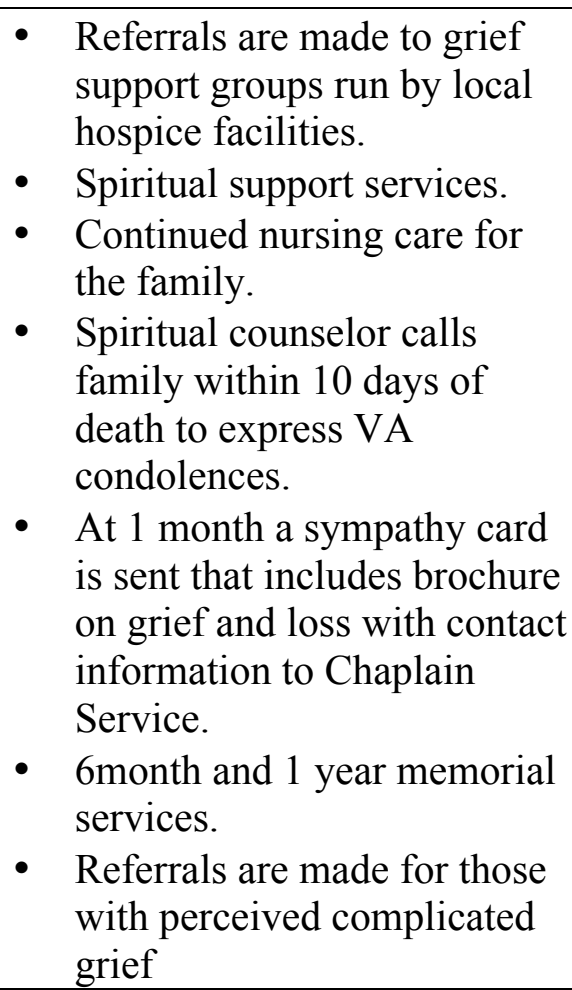 & $\begin{array}{ll}\text { - } & \text { Flyer of grief } \\
\text { support services } \\
\text { at local hospice } \\
\text { agencies. } \\
\text { - } \\
\text { Interviews with } \\
\text { staff. }\end{array}$ \\
\hline $\begin{array}{l}\text { 32. Document the } \\
\text { designated } \\
\text { surrogate/decision } \\
\text { maker in accordance } \\
\text { with state law for every } \\
\text { patient in primary, acute, } \\
\text { and long-term care and in } \\
\text { palliative and hospice } \\
\text { care. }\end{array}$ & $\begin{array}{l}\text { - At every level of VA } \\
\text { documentation in the } \\
\text { electronic record; capacity } \\
\text { for decision making and } \\
\text { designation of surrogate } \\
\text { decision maker is } \\
\text { documented. Legal } \\
\text { documentation of Health care } \\
\text { proxy is obtained especially } \\
\text { in complex social settings. } \\
\text { Intake of PCCT, the LICSW } \\
\text { and NP addresses code } \\
\text { status, health care proxy. }\end{array}$ & $\begin{array}{l}\text { - } \text { Chart audit. } \\
\text { - } \quad \text { Family meetings. }\end{array}$ \\
\hline
\end{tabular}




\begin{tabular}{|c|c|c|}
\hline Preferred Practices & Practice at VA & Evidence \\
\hline $\begin{array}{l}\text { 33. Document the } \\
\text { patient/surrogate } \\
\text { preferences for goals of } \\
\text { care, treatment options, } \\
\text { and setting of care at first } \\
\text { assessment and at } \\
\text { frequent intervals as } \\
\text { conditions change. }\end{array}$ & $\begin{array}{l}\text { Discussed early on in } \\
\text { palliative care plan and } \\
\text { reevaluated at changes in } \\
\text { patient condition or level of } \\
\text { care. Documented in } \\
\text { electronic record. }\end{array}$ & $\begin{array}{ll}\text { - } & \text { Chart audit. } \\
\text { - } & \text { Family meetings. }\end{array}$ \\
\hline $\begin{array}{l}\text { 34. Convert the patient } \\
\text { treatment goals into } \\
\text { medical orders, and } \\
\text { ensure that the } \\
\text { information is } \\
\text { transferable and } \\
\text { applicable across care } \\
\text { settings, including long- } \\
\text { term care, emergency } \\
\text { medical services, and } \\
\text { hospital care, through a } \\
\text { program such as the } \\
\text { Physician Orders for } \\
\text { Life-Sustaining } \\
\text { Treatment (POLST) } \\
\text { program. }\end{array}$ & $\begin{array}{l}\text { The patent's treatment goals } \\
\text { are converted into medical } \\
\text { orders by the medical team } \\
\text { and the PCCT. The VA has a } \\
\text { real time electronic charting } \\
\text { system so these are available } \\
\text { to all VA approved } \\
\text { providers. They would be } \\
\text { shared with an external } \\
\text { organization such as hospice } \\
\text { or skilled nursing facility. }\end{array}$ & $\begin{array}{ll}\text { - } & \text { Chart audit. } \\
\text { - } & \text { Interview with } \\
& \text { PCCT. }\end{array}$ \\
\hline $\begin{array}{l}\text { 35. Make advance } \\
\text { directives and } \\
\text { surrogacy designations } \\
\text { available across care } \\
\text { settings, while protecting } \\
\text { patient privacy and } \\
\text { adherence to HIPAA } \\
\text { regulations, for example, } \\
\text { by using Internet-based } \\
\text { registries or electronic } \\
\text { personal health records. }\end{array}$ & $\begin{array}{l}\text { Electronic records are } \\
\text { utilized at the VA including } \\
\text { interagency records. When } \\
\text { changes are made in the level } \\
\text { of care or plan of care there } \\
\text { are interagency staff } \\
\text { meetings to plan for } \\
\text { transition. Advance } \\
\text { directives and surrogacy } \\
\text { designations are } \\
\text { communicated and legal } \\
\text { documentation shared. }\end{array}$ & $\begin{array}{ll}- & \text { Chart audit. } \\
\text { - } & \text { Observation of } \\
\text { inter-agency } \\
\text { communication. }\end{array}$ \\
\hline $\begin{array}{l}\text { 36. Develop healthcare and } \\
\text { community } \\
\text { collaborations to } \\
\text { promote advance care } \\
\text { planning and the } \\
\text { completion of advance }\end{array}$ & $\begin{array}{l}\text { PCCT members are involved } \\
\text { in working with legislative } \\
\text { members in crafting } \\
\text { legislation regarding } \\
\text { palliative care and QOL act. } \\
\text { This is promoting advanced }\end{array}$ & $\begin{array}{ll}\text { - Interview with } \\
\text { PCCT. } \\
\text { - Legislative Bill } \\
\text { reviewed 2013- } \\
\text { H5204 }\end{array}$ \\
\hline
\end{tabular}




\begin{tabular}{|c|c|c|}
\hline Preferred Practices & Practice at VA & Evidence \\
\hline $\begin{array}{l}\text { directives for all } \\
\text { individuals, for example, } \\
\text { the Respecting Choices } \\
\text { and Community } \\
\text { Conversations on } \\
\text { Compassionate Care } \\
\text { programs. }\end{array}$ & $\begin{array}{l}\text { planning. } \\
\text { All patients are asked about } \\
\text { advance directives and given } \\
\text { information on how to obtain } \\
\text { and complete one. }\end{array}$ & $\begin{array}{ll}\text { - } & \text { State of RI. } \\
\text { - } & \text { Chart audits. }\end{array}$ \\
\hline $\begin{array}{l}\text { 37. Establish or have access } \\
\text { to ethics committees or } \\
\text { ethics consultation } \\
\text { across care settings to } \\
\text { address ethical conflicts } \\
\text { at the end of life. }\end{array}$ & $\begin{array}{l}\text { - There is an Ethic committee } \\
\text { in the VA inpatient hospital. } \\
\text { Most difficulties are } \\
\text { addressed with family/ team } \\
\text { meetings. The number of } \\
\text { referrals to ethics committee } \\
\text { has steadily decreased as } \\
\text { Palliative care services are } \\
\text { more available to patients. }\end{array}$ & 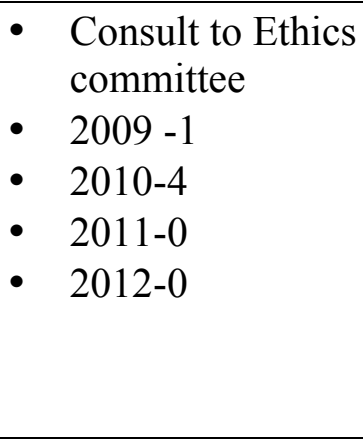 \\
\hline $\begin{array}{l}\text { 38. For minors with } \\
\text { decision making } \\
\text { capacity, document the } \\
\text { child's views and } \\
\text { preferences for medical } \\
\text { care, including assent for } \\
\text { treatment, and give them } \\
\text { appropriate weight in } \\
\text { decision making. Make } \\
\text { appropriate professional } \\
\text { staff members available } \\
\text { to both the child and the } \\
\text { adult decision maker for } \\
\text { consultation and } \\
\text { intervention when the } \\
\text { child's wishes differ from } \\
\text { those of the adult } \\
\text { decision maker. }\end{array}$ & $\begin{array}{l}\text { - } \mathrm{N} / \mathrm{A}- \\
\text { - The VA does not treat } \\
\text { minors. } \\
\text { - All patients are greater than } \\
18 \text { by nature of service. }\end{array}$ & \\
\hline
\end{tabular}




\section{Summary and Conclusions}

\section{Summary}

A program evaluation was completed at an in-patient acute care VA hospital. The CDC framework for program evaluation was used as the theoretical framework. The standards and guidelines published by the NQF were considered the standard of practice and the VA's practice was compared in both structure and process. The PCCT at the VA hospital meets many of the attributes and characteristics identified as essential markers of a quality palliative care program; $84.21 \%$ of the 38 standards were met completely and $15.78 \%$ of the standards were met partially.

\section{Completely Met Standards}

The team is comprised of a multi-disciplinary team of professionals trained in palliative care. The core team members consist of a NP, LICSW and spiritual counselor who collaborate with primary care physicians, medical specialists and medical teaching team to meet the needs of patients/families with chronic or advanced illnesses. There is a specific structure and process that supports the provision of palliative care services at the VA. The palliative care includes education for the patient/family, emotional, physical,

social and spiritual support, coordination of services and expert management of pain and other related symptoms associated with complex and advanced illnesses. The team supports the patient and family by facilitating discussions and decisions regarding goals of care and advance directives. The PCCT supports the patient/family by assisting in identification of goals of care and developing a patient centered plan of care. The palliative care team aids in consistent communication between the patient and all the 
members of the healthcare team including during times of transitions in a patient's care. Lastly, the care provided by the team includes care of the family, including grief and bereavement interventions after the death of the loved one.

There are many strengths of this palliative care program including distinct structure and process for referrals. The scope of practice by the palliative care team is well defined. The educational initiatives by the PCCT to other healthcare providers has been very successful as indicated by the increase in volume of referrals and the frequency of referrals made earlier in the disease progression. The members of the PCCT are passionate in their dedication to their patients and strong in their belief in the importance of quality palliative care. They provide expert symptom management addressing pain, anxiety, delirium, insomnia and other distressing symptoms often associated with serious illness. The unique cultural aspects of the veteran are considered when tailoring the plan of care for each patient. The team members possess strong communication skills. Having a LICSW and spiritual counselor as part of the PCCT demonstrates a focus and attention to all aspects of care including the social, emotional and spiritual domains of palliative care.

\section{Partially Met Standards}

The six standards that were deemed only partially met could be improved with some minimal changes such as the implementation of an evaluation tool to assess the patient/families satisfaction with symptom management. The VA does perform a bereavement survey to families of all patients that die in a VA facility. The purpose of this survey is to measure the entire team's attention to patients who are at end of life. 
This survey is inclusive of all the care received by the veteran and his family. It is not specific to the palliative care team management and more importantly it is performed after the patient has died. This is a clear limitation of the use of such an evaluation tool since it is too late to make adjustment that benefits the patient/family. It might be helpful to evaluate the patient and family satisfaction and concerns in real time using a validated tool so that alterations might be made quickly to the plan of care and thereby improving outcomes and satisfaction.

Some of the other standards that scored only partially satisfied were related to the limited scope of an acute care facility. It is not feasible for an acute care hospital team to meet all of these requirements alone. Due to limitations of the federal government in organizational structure and rules they are limited in the contractual relationships with external agencies such as a hospice agency. This may be perceived as a barrier in the transitioning of care of the palliative patient to hospice care. The PCCT does refer to outside agencies and facilities using an informal working relationship to meet the needs of their patients. Until the VA develops its own hospice team, these areas will remain in the scope of referral agencies.

Another limitation was the narrow community involvement by VA employees. The spiritual counselor acknowledged that he is guided by his federally defined scope of practice that limits his community involvement to those areas that are in direct support of a veteran or their family. Lastly, some cultural standards were only partially met based upon the lack of diversity of the team as well as limited access to interpreter services for families. 


\section{Limitations}

There are some limitations of this program evaluation. There was only one person performing the review, which is a singular perspective. The evaluation may have been affected by potential personal bias, as the evaluator worked closely with the PCCT. Some other limitations to this study were that it was heavily dependent upon personal interviews with the PCCT staff members. This creates the potential for bias as they may give answers that would promote a favorable perspective which may or may not be accurate. Lastly, the evaluation was limited by time constraints. While there was the opportunity to re-address staff members for missing data; access to chart reviews was no longer available. Nonetheless, the complete listing of the activities and results of evaluation are an effort to address these limitations. 


\section{Recommendations and Implications}

\section{Recommendations}

There are several areas for potential growth in the palliative care program. The team is small and very busy; the director has administrative and patient care responsibilities. Adding an additional member to the PCCT such as another NP could be very beneficial. A palliative care trained NP could provide the hands on medical care of the patients including symptom management thus allowing the director necessary time to devote to management, education of staff, promotion, and development of the program. This may not be feasible due to fiscal constraints; however, if the program continues to grow it may need to be reconsidered. Perhaps a 0.5 full time equivalent position could be phased in as the program expands.

Another manner in which the palliative care program might be more effective would be increasing the training of the bedside nurse in symptom management. The use of validated tools that measure anxiety, delirium, and dsypnea at the bedside might empower the bedside nurse to more effectively advocate and mange the care of the palliative care patient. Additionally, as the palliative care program continues to grow, it may be useful and feasible for the VA to consider developing its own hospice program or allow contracts with dedicated hospice centers to enhance communication and seamless transitions between levels of care.

Lastly, a method to evaluate the patient /family perceived satisfaction with care during acute hospitalization would strengthen the VA's ability in addressing any barriers or gaps in palliative care. A simple likert scale at the end of each PCCT visit asking the 
patient to rate the perceived benefit of palliative care service or identifying any unmet needs or issues might yield great benefit to the patient rather than a survey after death.

\section{Standards and Framework}

National guidelines and standards of both structure and process are important considerations for program development or improvement. They offer a framework for the initiation of new programs and serve as a tool by which to evaluate present programs. There are significant implications for a need of more standardized outcome measurements within the field of palliative care. While outcome measurements pose many challenges, especially in the palliative care patient, it perhaps offers the most significant area for improvement of symptoms and other domains significant to the patient and family.

It is important for programs to maintain data collection regarding the work that they do to reflect the benefits value and costs associated. The VA collects data to measure the federal mandates within the VA system for palliative care. Perhaps if a template such as the NQF's were utilized it would facilitate sharing of best palliative care practices to nongovernmental hospitals and agencies. This could also allow comparison of practice among different programs. The CDC framework served as a useful theoretical structure to support this evaluation. In addition to the $\mathrm{CDC}$ framework, clear standards and guidelines for best practice should be utilized in the development and evaluation of programs. 


\section{Advanced Practice Registered Nurses}

Palliative care is a growing and evolving healthcare field focused on relief of pain and other symptoms experienced by patients with advanced or chronic illnesses. Quality palliative care not only provides aggressive symptom management but also supports the patient and family to provide an optimum quality of life consistent with the values and goals of the patient.

An advanced practice registered nurses (APRN) is particularly well suited to meet the need for palliative care programs and the increasing healthcare demands of a growing, aging population with advanced levels of serious illnesses. The education of an APRN prepares them for many of the roles needed in providing palliative care. Nurses possess assessment skills uniquely suited for the holistic approach to palliative care. Their training includes learning how to help people; they historically are the caregivers at the bedside and give witness to the difficult symptoms experienced by those seriously ill with life threatening illnesses. They are taught to provide care by addressing the needs of their patients in the physical, psychological and spiritual domains. Nurses advocate for their patients; they utilize their assessment skills, communication skills and care giving skills to promote patient safety as well as implementing interventions that diminishes pain and suffering. Nurses are qualified educators. They teach patients and families necessary skills to manage their health /illnesses.

The Hospice and Palliative Care: Scope and Standards of Practice (ANA/HPNA, 2007) book provides the extent of the scope and the minimal standards of practice for both registered nurses and advanced practice registered nurses. Advanced practice nurses, 
when prepared to follow these guidelines, can and should assume a pivotal role in coordinating, directing and or providing care within this evolving specialty.

\section{Conclusion}

Palliative care is a growing specialty that meets the healthcare needs of people suffering with the effects of chronic and serious health issues. Specially trained interdisciplinary team members provide supportive care for patients and their families. The number of palliative care programs are increasing rapidly in response to this healthcare demands. National standards and guidelines serve to establish a model for the development and evaluation of quality palliative care programs. APRN's have the skills necessary thus the ability to play a pivotal role in the development, coordination, provision, and evaluation of palliative care programs. 


\section{References}

Agency for Healthcare Research and Quality (2012). National Healthcare Quality Report, 2011 Retrieved from: http://www.ahrq.gov/qual/nhqr11/chap1.htm

American Nurses Association (2007).Hospice and palliative care scope and standards of practice, Edition 4.

Anadarojah, G., \& Hight, E., (2001). Spirituality and medical practice: Using the HOPE questions as a practical tool for spiritual assessment. American Family Physician. Jan 1:63 (1) 81-89.

Bakitas, M., Bishop, M. F., Caron, P., \& Stephens, L. (2010, November). Developing successful models of cancer palliative care services. Seminars in Oncology Nursing, 26(4), 266-284. doi:10.1016/j.sonen.2010.08.006

Bausewein, C., LeGrice, C., Simon, S., \& Higginson, I. (2011). The use of two common palliative outcome measures in clinical care and research: A systematic review of the POS and STAS. Palliative Medicine, 25 (4), 304-313. doi:

$10.1177 / 0269216310395984$

Center for Disease Control and Prevention. (1999, September 17). Framework for program evaluation in public health Retrieved from CDC: http://www.cdc.gov/eval.framework/index.htm

Center to Advance Palliative Care. (2011, July, 14). Palliative care in hospitals continues rapid growth for tenth straight year, according to latest analysis Retrieved from Center to Advance Palliative Care: http://www.capc.org/news-andevents/releases/07-14-11 
Connor, S. R. (2007). Development of hospice and palliative care in the United States. Omega, 56(1), 89-99. doi:10.2190/OM56.1h

De Lima, L., Bennett, M. I., Murray, S. A., Hudson, P., Doyle, D., Bruera, E....Wenk, R. (2012). International association for hospice and palliative care (IAHPC) list of essential practices in palliative care. Journal of Pain and Palliative Care Pharmacotherapy, 26, 118-122. doi:10.3109/15360288.2012.680010

Dy, S., Lupu, D., \& Scow, H. (2012). Progress towards systems of quality measures that capture the essence of good palliative care. Palliative Medicine, 26 (4), 291-293. doi: $10.1177 / 02692163124496$

Eagar, K., Walters, P., Crow, D. C., Aoun, S. M., \& Yates, P. (2010, May). The Australian palliative care outcomes collaboration (PCOC) Measuring the quality and outcomes of palliative care on a routine basis. Australian Health Review, 34(2), 186-192. doi:10.1071/AH0878180156-5788/10/020186

Hanson, L. C., Scheunemann, L. P., Zimmerman, S., Roakoske, F. S., \& Schenck, A. P. (2010). The PEACE project review of clinical instruments for hospice and palliative care. Journal of Palliative Medicine, 13(10), 1253-1260.

doi:10.1089/jpm.2010.0194

Hauser, J., Araneta, N., Martinez, J., Finn, K., Calista, J., Calcano, E.,...Rodrigue, M. K. (2011, August 1). Navigation and Palliative Care. Cancer, 117(15)3585-3591. doi:10.1002/cncr.26266 
Hearn, J., \& Higgins, I. J. (1999). Development and validation of a core outcome measure for palliative care: the palliative outcome scale. Quality in Healthcare, 8 , 219-227.

Institute of Medicine. (2001). Crossing the quality Chasm: A new health care system for the 21st century [Policy brief]. Retrieved from Institute of Medicine: http://iom.edu/Reports/2001/Crossing-the-Quality-Chasm-A-New-HealthSystem-for-the-21st-Century.aspx

Jocham, H. R., Dassen, T., Widderhoven, G., \& Halfens, R. (2009). Evaluating palliative care- A review of the literature. Palliative Care Research and Treatment, 3, 5-12.

Milstein, B., \& Wetterhall, S. (2000, July). A framework featuring steps and standards for program evaluation. Health Promotion Practice, 1 (3), 221-228.

Morrison, R.S., Maroney-Galin, C., Kralovec, P., \& Meier, D. (2005) The growth of palliative care programs in the United States hospitals. Journal of Palliative Care Medicine 8(6)1127-1134.

Mularski, R. A., Curtis, J. R., Billings, A., Burt, R., Byick, I., Fuhrman, C.,...Levy, M. M. (2006). Proposed quality measures for palliative care in the critically ill: A consensus from the Robert Wood Johnson foundation critical care workgroup. Critical Care Medicine, 34(11) s404-s411. doi:10.1097/01.CCM.0000242910.00801.53

National Consensus Project for Palliative Care. (2004). National consensus project for quality palliative care clinical practice guidelines for quality palliative care, executive summary. Journal of Palliative Medicine, 7(5) 611-627. 
National Consensus Project for Quality Palliative Care. (2009). Clinical Practice Guidelines for Quality Palliative Care, Second Edition. Retrieved from National Consensus Project.org: http://www.nationalconsesusproject.org

National Hospice and Palliative Care Organization. (2012). History of hospice care: $a$ historical perspective. Retrieved from The National Hospice and Palliative Care Organization: http://www.nhpco.org/i4a/pages/index.cfm?pageid=3285

National Institute of Health. (2005, February 18). National institutes of health state-ofthe-science conference statement: Improving end of life care. Retrieved from National Institutes of Health: Department of Health and Human Services: http://www.ninr.nih.gov/ ResearchAndFunding/SpotlightonEndofLifeResearch/

National Palliative Care Research Center. (2013, April 10). Pain and symptom management. Retrieved from http://www.npcrc.org/resources/resources_show.htm?doc_id=376168

National Quality Forum (NQF) Consensus Report. (2006). A national framework and preferred practices for palliative and hospice care quality. Retrieved from National Quality Forum: http://www.qualityforum.org/Projects/nr/Palliative_and_Hospice_Care_Framework/Palliative__Hospice_Care_Frame work_and_Practices.aspx

Nolte, E. (2010, March 5). International benchmarking of healthcare quality: A review of the literature. Retrieved from Rand.org: http://search.rand.org/pubs/periodicals/health-quarterly/issues/v1/n4/06.html 
Pastrana, T., Junger, S., Ostegathe, C., Elsner, F., \& Radbruch, L. (2008). A matter of definition Key elements identified in a discourse analysis of definitions of palliative care. Palliative Medicine, 22, 222-232. doi:

$10.1177 / 0069216308089803$

Schenck, A. P., Roakoske, F. S., Durham, D. D., Cagle, J. G., \& Hanson, L. C. (2010). The PEACE project: Identification of quality measures for hospice and palliative care. Journal of Palliative Medicine, 13(12), 1421-1459. doi:10.1089/jpm.2010.0238

Selman, L., \& Harding, R. (2010,). How can we improve outcomes for patients and families under palliative care? Implementing clinical audit for quality improvement in resource limited settings. Indian Journal of Palliative Care, 16, 8-15. doi:10.4103/0973-1075.63128

Shreva, S. (2010). Hospice and palliative care by the VA, beyond the VA. Journal of the American Society of Aging, 34 (2), 49-56.

The Joint Commission. (2011, September). Advance certification for palliative care programs Retrieved from The Joint Commission: http://www.jointcommission.org/certification/palliative_care.aspx

Twaddle, M. L., Maxwell, T. L., Cassel, B., Liao, S., Coyne, P. J., Usher, B. M.,...Cuny, J. (2007). Palliative care benchmarks from academic medical centers. Journal of Palliative Medicine, 19(1), 86-98. doi:10.1089/jpm.2006.0048 
Weissman, D. E., \& Meir, D.E. (2008) Operational features for hospital palliative care programs: Consensus recommendations. Journal of Palliative Medicine, 11(9) 1189-1194. Doi:10.1089/jpm.2008.0149

Weissman, D.E., Meir, D.E., \& Spragene, L. (2010) Center to advance palliative care palliative care clinical care and customer satisfaction metrics: Consensus recommendations. Journal of Palliative Medicine, 13(2) 179-184.doi 10.1089/jpm.2009.0270

World Health Organization. (2012).WHO definition of palliative care. Retrieved from World Health Organization: http//www.who.int/cancer/palliative/definition/en/ 
Appendix A

A National Framework and

Preferred Practices for Palliative and Hospice Care Quality

A National Quality Forum (NQF) Consensus Report

\section{Preferred Practices...}

I. Provide palliative and hospice care by an interdisciplinary team of skilled palliative care professionals, including, for example, physicians, nurses, social workers, pharmacists, spiritual care counselors, and others who collaborate with primary healthcare professional(s).

2. Provide access to palliative and hospice care that is responsive to the patient and family 24 hours a day, 7 days a week.

3. Provide continuing education to all healthcare professionals on the domains of palliative care and hospice care.

4. Provide adequate training and clinical support to assure that professional staff is confident in their ability to provide palliative care for patients.

5. Hospice care and specialized palliative care professionals should be appropriately trained, credentialed, and/or certified in their area of expertise.

6. Formulate, utilize, and regularly review a timely care plan based on a comprehensive interdisciplinary assessment of the values, preferences, goals, and needs of the patient and family and, to the extent that existing privacy laws permit, ensure that the plan is broadly disseminated, both internally and externally, to all professionals involved in the patient's care.

7. Ensure that upon transfer between healthcare settings, there is timely and thorough communication of the patient's goals, preferences, values, and clinical information so that continuity of care and seamless follow-up are assured.

8. Healthcare professionals should present hospice as an option to all patients and families when death within a year would not be surprising and should reintroduce the hospice option as the patient declines.

9. Patients and caregivers should be asked by palliative and hospice care programs to assess physicians'/healthcare professionals' ability to discuss hospice as an option.

10. Enable patients to make informed decisions about their care by educating them on the process of their disease, prognosis, and the benefits and burdens of potential interventions.

II. Provide education and support to families and unlicensed caregivers based on the patient's individualized care plan to assure safe and appropriate care for the patient. 
12. Measure and document pain, dsypnea, constipation, and other symptoms using available standardized scales.

13. Assess and manage symptoms and side effects in a timely, safe, and effective manner to a level that is acceptable to the patient and family.

14. Measure and document anxiety, depression, delirium, behavioral disturbances, and other common psychological symptoms using available standardized scales.

I5. Manage anxiety, depression, delirium, behavioral disturbances, and other common psychological symptoms in a timely, safe, and effective manner to a level that is acceptable to the patient and family.

16. Assess and manage the psychological reactions of patients and families (including stress, anticipatory grief, and coping) in a regular, ongoing fashion in order to address emotional and functional impairment and loss.

17. Develop and offer a grief and bereavement care plan to provide services to patients and families prior to and for at least 13 months after the death of the patient.

18. Conduct regular patient and family care conferences with physicians and other appropriate members of the interdisciplinary team to provide information, to discuss goals of care, disease prognosis, and advance care planning, and to offer support.

19. Develop and implement a comprehensive social care plan that addresses the social, practical, and legal needs of the patient and caregivers, including but not limited to relationships, communication, existing social and cultural networks, decision making, work and school settings, finances, sexuality/intimacy, caregiver availability/stress, and access to medicines and equipment.

20. Develop and document a plan based on an assessment of religious, spiritual, and existential concerns using a structured instrument, and integrate the information obtained from the assessment into the palliative care plan.

21. Provide information about the availability of spiritual care services, and make spiritual care available either through organizational spiritual care counseling or through the patient's own clergy relationships.

22. Specialized palliative and hospice care teams should include spiritual care professionals appropriately trained and certified in palliative care.

23. Specialized palliative and hospice spiritual care professionals should build partnerships with community clergy and provide education and counseling related to end-of-life care. 
24. Incorporate cultural assessment as a component of comprehensive palliative and hospice care assessment, including but not limited to locus of decision making, preferences regarding disclosure of information, truth telling and decision making, dietary preferences, language, family communication, desire for support measures such as palliative therapies and complementary and alternative medicine, perspectives on death, suffering, and grieving, and funeral/burial rituals.

25. Provide professional interpreter services and culturally sensitive materials in the patient's and family's preferred language.

26. Recognize and document the transition to the active dying phase, and communicate to the patient, family, and staff the expectation of imminent death.

27. Educate the family on a timely basis regarding the signs and symptoms of imminent death in an age-appropriate, developmentally appropriate, and culturally appropriate manner.

28. As part of the ongoing care planning process, routinely ascertain and document patient and family wishes about the care setting for the site of death, and fulfill patient and family preferences when possible.

29. Provide adequate dosage of analgesics and sedatives as appropriate to achieve patient comfort during the active dying phase, and address concerns and fears about using narcotics and of analgesics hastening death.

30. Treat the body after death with respect according to the cultural and religious practices of the family and in accordance with local law.

31. Facilitate effective grieving by implementing in a timely manner a bereavement care plan after the patient's death, when the family remains the focus of care.

32. Document the designated surrogate/decision maker in accordance with state law for every patient in primary, acute, and long-term care and in palliative and hospice care.

33. Document the patient/surrogate preferences for goals of care, treatment options, and setting of care at first assessment and at frequent intervals as conditions change.

34. Convert the patient treatment goals into medical orders, and ensure that the information is transferable and applicable across care settings, including long-term care, emergency medical services, and hospital care, through a program such as the Physician Orders for Life-Sustaining Treatment (POLST) program.

35. Make advance directives and surrogacy designations available across care settings, while protecting patient privacy and adherence to HIPAA regulations, for example, by using Internet-based registries or electronic personal health records. 
36. Develop healthcare and community collaborations to promote advance care planning and the completion of advance directives for all individuals, for example, the Respecting Choices and Community Conversations on Compassionate Care programs.

37. Establish or have access to ethics committees or ethics consultation across care settings to address ethical conflicts at the end of life.

38. For minors with decision making capacity, document the child's views and preferences for medical care, including assent for treatment, and give them appropriate weight in decision making. Make appropriate professional staff members available to both the child and the adult decision maker for consultation and intervention when the child's wishes differ from those of the adult decision maker. 